Review Article

\title{
Tectonic classification of Cenozoic Iberian foreland basins
}

\author{
G. De Vicente ${ }^{\mathrm{a}, *}$, S. Cloetingh ${ }^{\mathrm{b}}$, J.D. Van Wees ${ }^{\mathrm{b}, \mathrm{c}}$, P.P. Cunha ${ }^{\mathrm{d}}$ \\ a Dpto. Geodinámica, F.C. Geológicas, Universidad Complutense, Instituto de Geociencias CSIC-UCM, Madrid, Spain \\ ${ }^{\mathrm{b}}$ Faculty of Earth and Life Sciences, VU University, Amsterdam, The Netherlands \\ c TNO, Princetonlaan 6, 3584 CB Utrecht, The Netherlands \\ ${ }^{\mathrm{d}}$ Dep. of Earth Sciences, IMAR-Marine and Environmental Research Centre, University of Coimbra, Portugal
}

\section{A R T I C L E I N F O}

\section{Article history:}

Received 18 September 2009

Received in revised form 15 July 2010

Accepted 14 February 2011

Available online 2 March 2011

\section{Keywords:}

Cenozoic

Iberia

Basin analysis

Deformation

Scale

\begin{abstract}
A B S T R A C T
The Iberian microcontinent stands out because of its intense Alpine intraplate deformation. This is reflected in a large number of Cenozoic basins of very different sizes. Most of the contacts between topographic highs and basins are thrust or strike-slip faults. All these basins seem to have undergone a common sedimentary evolution, comprising four stages: initiation of sedimentation, intense syn-tectonic infilling, change from endorheic to exorheic drainage, and accelerated erosion related to fluvial incision. This simple evolutionary model shows a migration from East to West, in which basins are still tectonically active at the Atlantic margin of Iberia. This common evolution is also found in a series of geometrical characteristics, such as the ratio $r$ of length of strike-slip fault and length of thrust fault, that are very similar in both types of basin border settings. Thrust-related basins are mainly associated with segmented pop-downs, whereas the main basins have the characteristics of open-ramp basins. Strike-slip related basins are mostly transpressive structures, although small pull-apart basins are usual along the Vilariça and Messejana faults. For basin areas larger than 100$1000 \mathrm{~km}^{2}$, a constant $r$ value of 0.6 is found (including the Ebro, Duero, Madrid, Lower Tagus and Badajoz basins). Within the Iberian microcontinent, the total amount of Cenozoic contractional deformation was distributed between strike-slip and thrust faults with an $r$ ratio close to 0.6. However, for small basins this parameter seems to depend on the type of fault, range or deformation belt (pure strike-slip, transtension, transpression, and pop-up) independently of its local tectonic development.
\end{abstract}

(c) 2011 Elsevier B.V. All rights reserved.

\section{Contents}

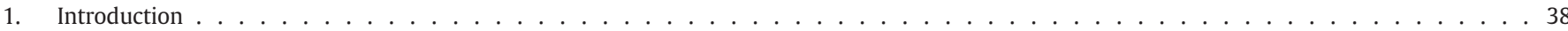

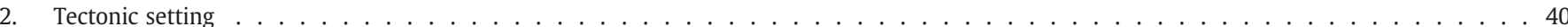

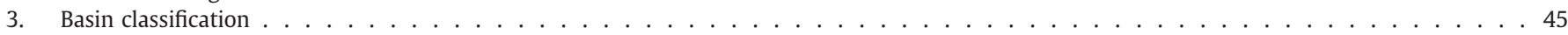

4. Iberian intramontane foreland basins of Cenozoic age . . . . . . . . . . . . . . . . . . . . . . . . . . 46

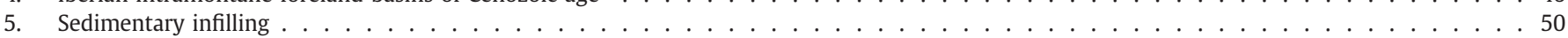

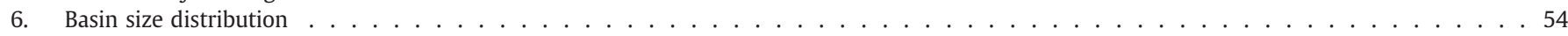

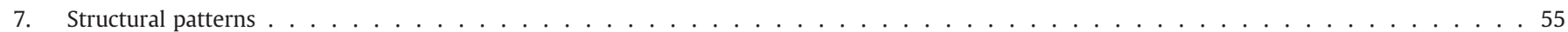

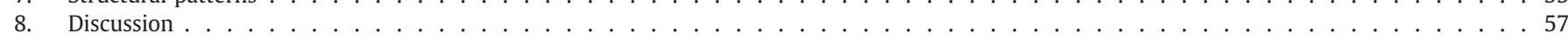

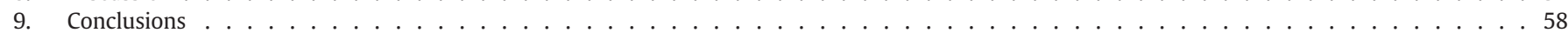

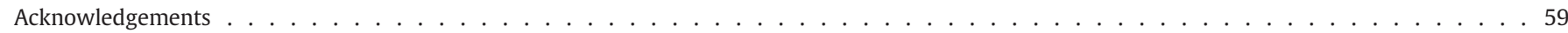

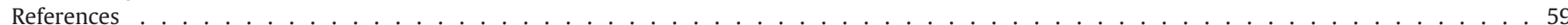

\footnotetext{
* Corresponding author. Tel. +34 913944827.
}

E-mail address: gdv@geo.ucm.es (G. De Vicente).

\section{Introduction}

The plate tectonics evolution of the Iberian microplate during the Cenozoic led to a drastic change in the topography of its continental part. From an average elevation close to sea level until the end of the Cretaceous (e.g. Cunha and Pena dos Reis, 1995; Dinis et al., 2008), the 


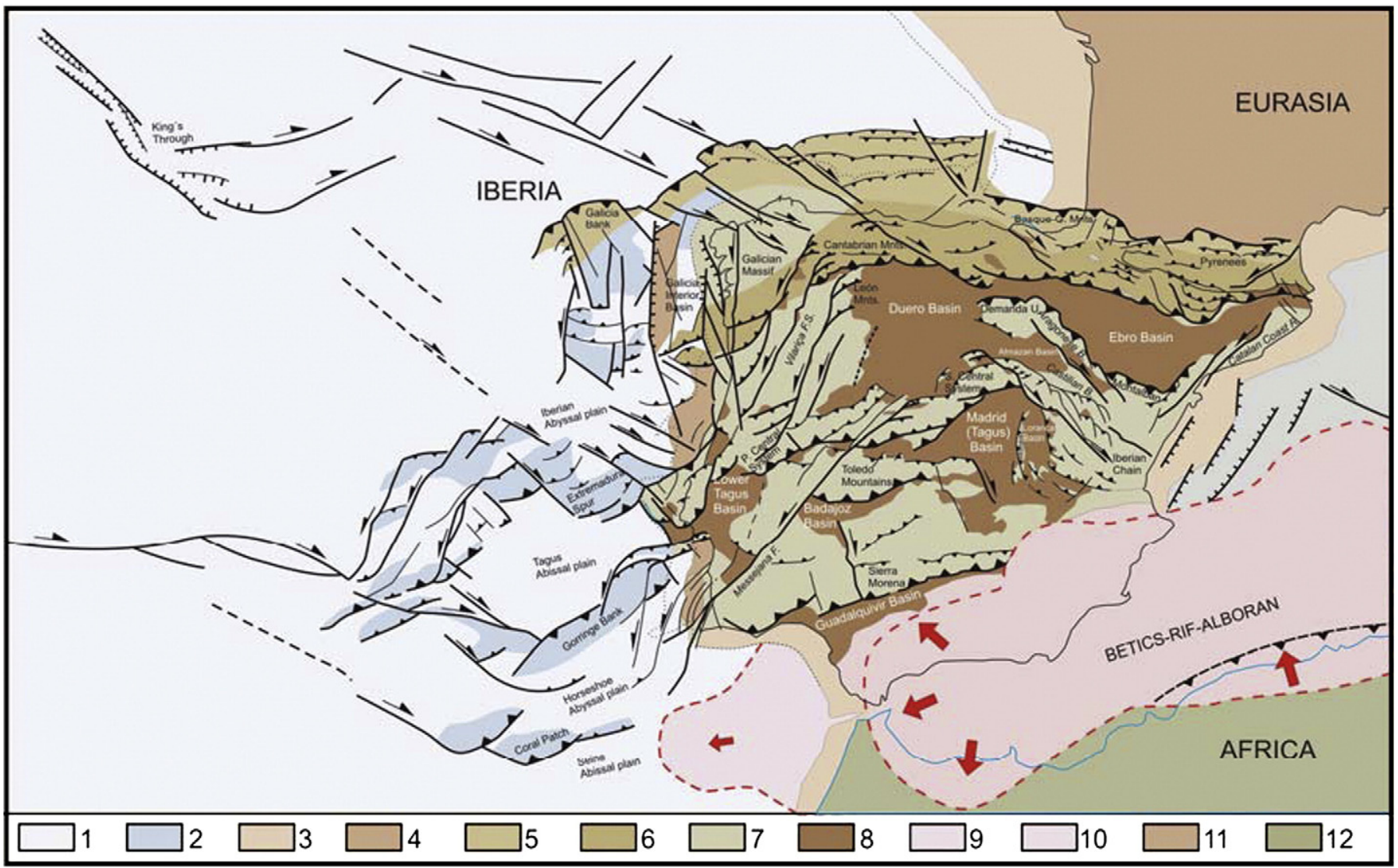

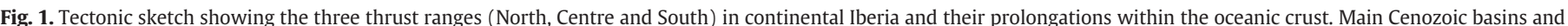

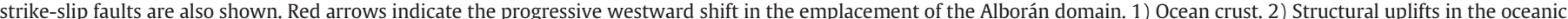

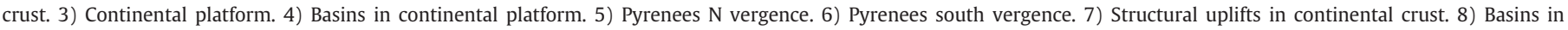
continental crust. 9) Alborán domain. 10) Gulf of Cádiz fan. 11) Eurasia continental crust. 12) Africa continental crust.

Cretaceous planation surface is now commonly uplifted about 100$600 \mathrm{~m}$, with mountain belts rising to $2000 \mathrm{~m}$. During the Cenozoic, several basement uplifts and sedimentary basins were formed. These basins were located in areas that were subsiding relative to the ranges, where sediments accumulated to form successions up to $3500 \mathrm{~m}$ thick (e.g. Madrid Basin; Lanaja, 1986).

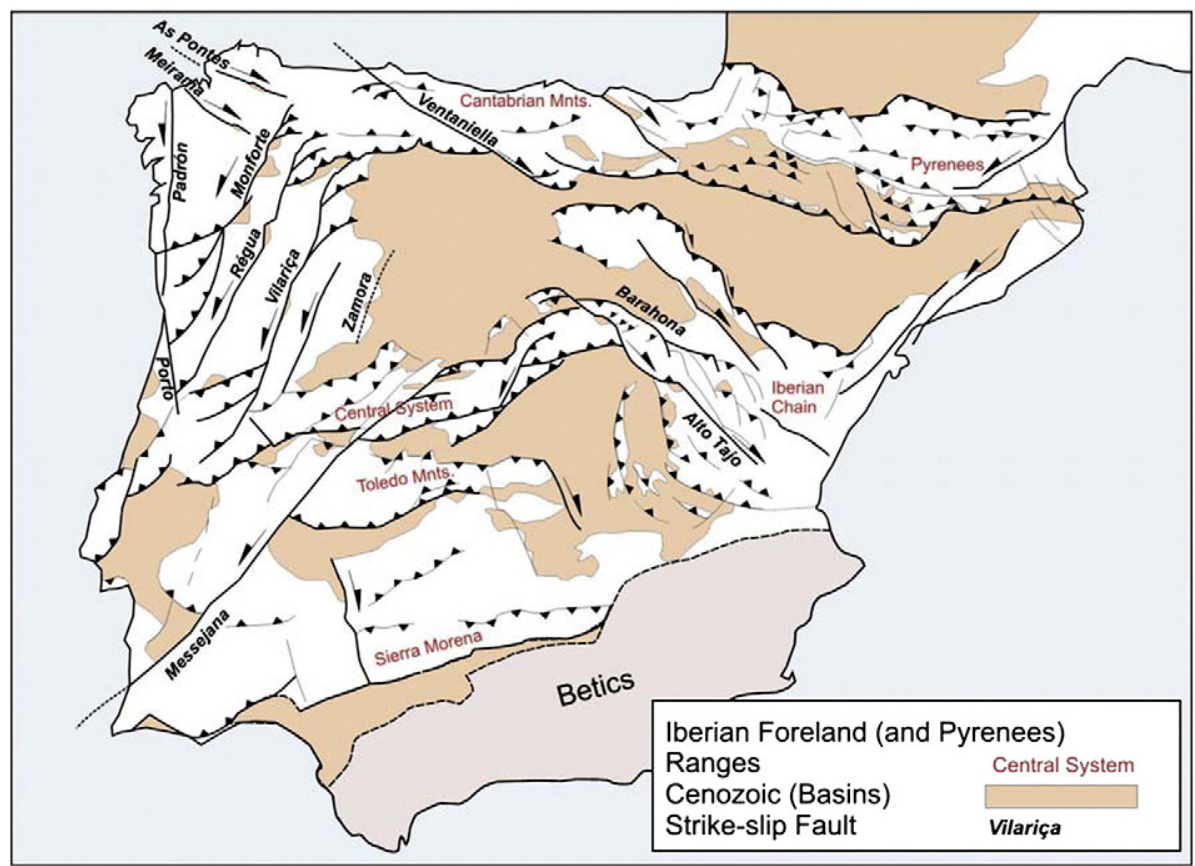

Fig. 2. Main strike-slip faults and ranges in the Iberian foreland (De Vicente and Vegas, 2009). 


\section{Restraining bend related basin (Without cover)}

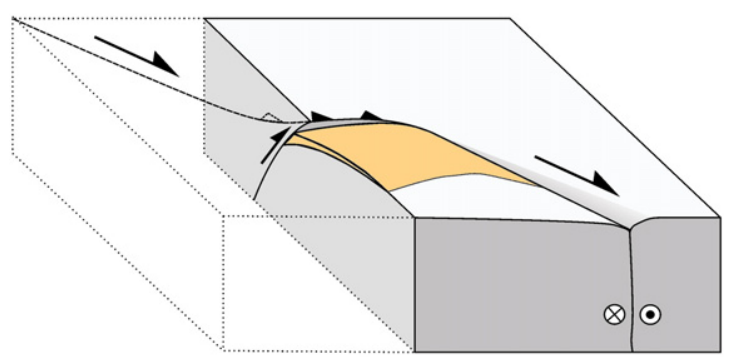

\section{Restraining bend related basin (With cover)}

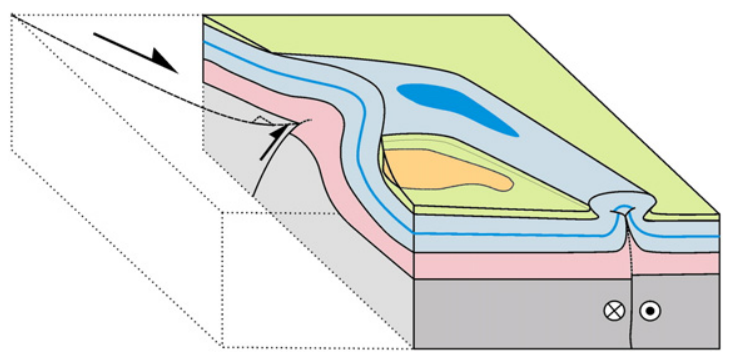

Fig. 3. Tectonic interpretation of transpressive-related basins (with and without sedimentary cover). This model explains the differences between the Iberian Chain (with sedimentary cover) and the western strike-slip deformation belts (without cover).

Broadly speaking, there are three main uplifted zones in the Iberian microplate: 1) the Pyrenees, Cantabrian mountains, Galicia Massif and Bank, and Western Portuguese Mountains, in the north and northwest; 2) the Iberian Chain (Range), Central System (Spanish and Portuguese), Estremenho Massif and Extremadura Spur in the centre; and 3) a zone of low relief in the south (Fig. 1). In these uplifted belts, contact with the main basins is always through thrusting, but reverse faulting is also found within the small intramontane (pop-down) basins in the interior of the ranges (Fig. 2).

Connecting these three structural uplifts, and also sectoring the main crustal thrusts, left-lateral NNE-SSW and right-lateral NW-SE strike-slip deformation belts take on part of the deformation in the interior of Iberia (Santanach, 1994; Vegas et al., 2004; De Vicente et al., 2005a, b). Flexural basins were formed among these main basement uplifts, while small basins related to the strike-slip faults were also developed during the Cenozoic.

Different classifications of the Iberian Cenozoic basins have been undertaken based upon their relationship with the Pyrenean or the Betic orogenies, or linked to their intraplate location (e.g. Friend and Dabrio, 1996; Gibbons and Moreno, 2002). More recent compilations have classified the Iberian basins according to the type of basement (Variscan or Mesozoic) (Civis, 2004 in Vera, 2004). At the moment, important information is lacking for a better understanding of the Iberian foreland system. In this paper, we aim to bring together different data to provide an integrated tectonic perspective.

While the tectonic setting is the key criterion in the classification of different types of sedimentary basins, the scale of observation also plays an important role. Here, we follow a tectonic approach to classify the Iberian (foreland) Cenozoic basins, from the largest scale to the singlefault basin scale. We use tectonic mapping, correlation between plate tectonic events and basin filling, and the dimensions of the main flexural basins and strike-slip basins in order to gain a better understanding of the foreland basin system. We demonstrate that very different deformation styles and associated basin infilling features have been conditioned by a differentiated tectonic response to phases of rather homogeneous tectonic stresses on an intraplate scale, in an area where multi-scale strain partitioning plays an important role.

\section{Tectonic setting}

The northern edge of the Iberian Peninsula consist of a series of mountain ranges running the whole way from the Mediterranean to the Atlantic margin (Figs. 1,2). The eastern, intra-continental segment of this belt corresponds to the Pyrenees, a collisional orogeny along

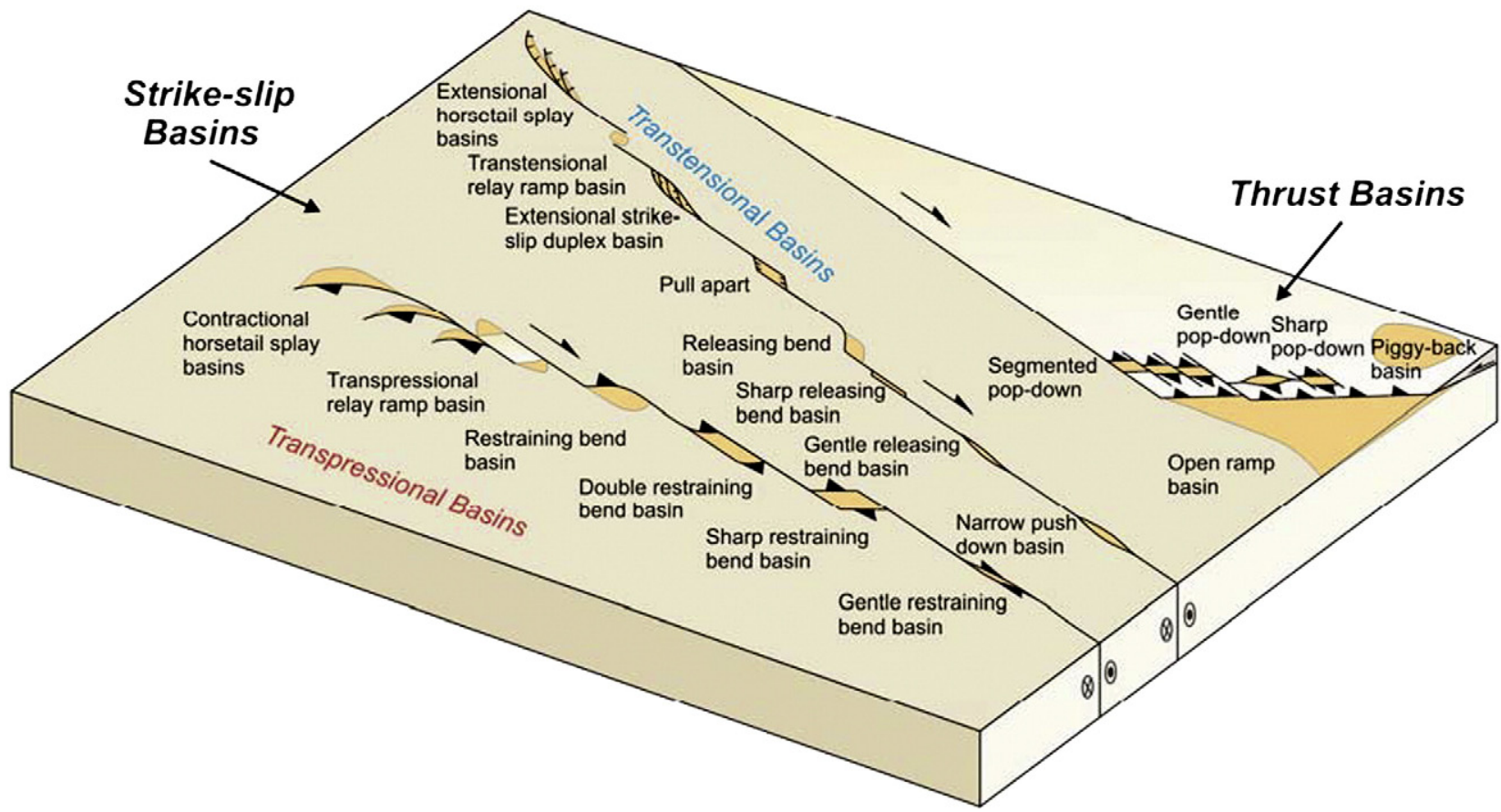

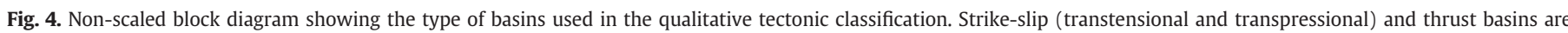
differentiated. 
Table 1

Table of the analyzed basins from the Iberian foreland. Every individual basin is related to a basement uplift or to a main fault. Numbers used in all figures are also shown.

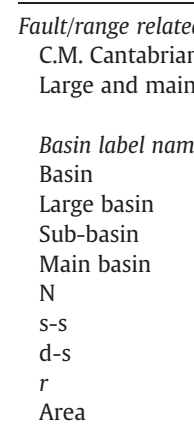

La Pela

La Mancha

Almazán (Duero)

Ebro

Basin number (same in all figures).

Length of the strike-slip faulting affecting the basin borders (km).

Length of the dip-slip (thrust faulting except, * normal faulting) affecting the basin borders. ratio $(\mathrm{s}-\mathrm{s}) /(\mathrm{d}-\mathrm{s})$

$\left(\mathrm{km}^{2}\right)$

(-) indicates that the measurement was not possible.

\begin{tabular}{|c|c|c|c|c|c|c|}
\hline Fault/range & Basin & $\mathrm{N}$ & $S-s$ & $\mathrm{~d}-\mathrm{s}$ & $r$ & Area \\
\hline As Pontes & Cantarallana & 1 & 6 & 5 & 1.2 & 13 \\
\hline As Pontes & As Pontes & 2 & 12.5 & 10 & 1.25 & 24 \\
\hline \multirow[t]{2}{*}{ As Pontes } & Roupar & 3 & 5.5 & 4 & 1.4 & 14 \\
\hline & Vilalba & 4 & 20 & $(-)$ & $(-)$ & 300 \\
\hline Meirama & Laracha & 5 & 1.5 & 3 & 0.5 & 5 \\
\hline Meirama & Meirama & 6 & 4.5 & 1 & 4.5 & 4 \\
\hline Meirama & Visantoña & 7 & 1.5 & 1.5 & 1 & 3 \\
\hline Meirama & Xanceda & 8 & 2.5 & 0.5 & 5 & 3 \\
\hline Meirama & Boimorto & 9 & 2 & 0.5 & 4 & 3 \\
\hline Monforte & Sarria & 10 & 17 & 13 & 1.3 & 160 \\
\hline Monforte & Monforte & 11 & 33 & 32 & 1.0 & 1140 \\
\hline Monforte & Xinzo de Limia & 12 & 50 & 52 & 0.96 & 1700 \\
\hline Régua & Verín & 13 & 8 & $20^{*}$ & 0.4 & 45 \\
\hline Régua & Chaves & 14 & 10 & 3 & 3.3 & 30 \\
\hline Régua & Vila Real & 15 & 4 & $(-)$ & $(-)$ & 2 \\
\hline Régua & Besteiros & 16 & $(-)$ & $(-)$ & $(-)$ & $(-)$ \\
\hline Régua & Mortágua & 17 & $(-)$ & $(-)$ & $(-)$ & $(-)$ \\
\hline Vilariça & Bragança & 18 & $(-)$ & $(-)$ & $(-)$ & $(-)$ \\
\hline Vilariça & Vilariça & 19 & 11 & $3^{*}$ & 3.6 & 12 \\
\hline Vilariça & Longroiva & 20 & 5.5 & $1.5^{*}$ & 3.7 & 6 \\
\hline C.M. & El Bierzo & 21 & 66 & 95 & 0.7 & 4780 \\
\hline C.M. & Rasa & 22 & $(-)$ & $(-)$ & $(-)$ & $(-)$ \\
\hline \multirow[t]{2}{*}{ C.M. } & Narcea (Boinás) & 23 & 3 & 15 & 0.2 & $15 ?$ \\
\hline & Macedo de Cavaleiros & 24 & $(-)$ & $15 ?$ & $(-)$ & 30 \\
\hline Ventaniella (C.M.) & Oviedo & 25 & 30 & 40 & 0.75 & 700 \\
\hline Ventaniella (C.M.) & Bureba (Duero) & 26 & $(-)$ & $(-)$ & $(-)$ & $(-)$ \\
\hline Messejana & Plasencia & 27 & 8.5 & $2.4^{*}$ & 3.5 & 14 \\
\hline Messejana & Moro & 28 & 3 & $1^{*}$ & 3 & 2 \\
\hline Messejana & Cañaveral & 29 & 14 & $4^{*}$ & 3.5 & 32 \\
\hline Messejana & Rivera de Araya & 30 & 8 & $2.5^{*}$ & 3.2 & 8 \\
\hline Messejana & Lucefeci & 31 & 3 & 2 & 1.5 & 6 \\
\hline Messejana & Montoito & 32 & 5 & 7 & 0.7 & 30 \\
\hline Messejana & Dermira & 33 & 16 & $7^{*}$ & 2.3 & 38 \\
\hline \multirow[t]{4}{*}{ Messejana } & Aljezur & 34 & 14 & $3^{*}$ & 4.6 & 10 \\
\hline & Algarve & 35 & 15 & 34 & 0.4 & 340 \\
\hline & Torrejón & 36 & $(-)$ & $(-)$ & $(-)$ & $(-)$ \\
\hline & Lusitanian & 37 & 80 & 100 & 0.8 & 15,700 \\
\hline Central System & Mondego & 38 & 15 & 28 & 0.5 & 1100 \\
\hline Central System & Sarzedas & 39 & 15 & 22 & 0.7 & 75 \\
\hline Central System & Lower Tagus & 40 & 100 & 170 & 0.58 & 33,000 \\
\hline Central System & Moraleja & 41 & 40 & 101 & 0.4 & 5800 \\
\hline Central System & Coria & 42 & 52 & 58 & 0.9 & 1500 \\
\hline Central System & Zarza de Granadilla & 43 & 12 & 16 & 0.75 & 90 \\
\hline Central System & Campoarañuelo (Madrid) & 44 & $(-)$ & $(-)$ & $(-)$ & $(-)$ \\
\hline Central System & Corneja & 45 & 14 & 22 & 0.6 & 350 \\
\hline Central System & Cepeda & 46 & 2 & 25 & 0.1 & 70 \\
\hline Central System & Amblés & 47 & 30 & 76 & 0.4 & 1300 \\
\hline Central System & Campoazálvaro & 48 & 12 & 24 & 0.5 & 250 \\
\hline \multirow[t]{7}{*}{ Central System } & Lozoya & 49 & 14 & 48 & 0.3 & 265 \\
\hline & Ciudad Rodrigo (Duero) & 50 & $(-)$ & $(-)$ & $(-)$ & $(-)$ \\
\hline & Duero & 51 & 530 & 550 & 0.96 & 196,000 \\
\hline & Madrid & 52 & 235 & 480 & 0.49 & 103,620 \\
\hline & Badajoz & 53 & 100 & 160 & 0.62 & 26,400 \\
\hline & Vegas Bajas (Badajoz) & 54 & $(-)$ & $(-)$ & $(-)$ & $(-)$ \\
\hline & Loranca (Madrid) & 55 & $(-)$ & $(-)$ & $(-)$ & $(-)$ \\
\hline Iberian Range & La Pela & 56 & 12 & 11 & 1.1 & 52 \\
\hline Iberian Range & Zaorejas & 57 & 7 & 12 & 0.6 & 250 \\
\hline Iberian Range & Piqueras & 58 & 7 & 11 & 0.63 & 180 \\
\hline Iberian Range & Alcorón & 59 & 13 & 3 & 4.3 & 70 \\
\hline
\end{tabular}


Table 1 (continued)

\begin{tabular}{|c|c|c|c|c|c|c|}
\hline Fault/range & Basin & $\mathrm{N}$ & s-s & d-s & $r$ & Area \\
\hline Iberian Range & Alto Tajo & 60 & 15 & 3 & 5 & 9 \\
\hline Iberian Range & Cabriel & 61 & 12 & 2 & 6 & 8 \\
\hline Iberian Range & Calatayud (Daroca) & 62 & $(-)$ & $(-)$ & $(-)$ & $(-)$ \\
\hline \multirow[t]{5}{*}{ Iberian Range } & Almazán (Duero) & 63 & $(-)$ & $(-)$ & $(-)$ & $(-)$ \\
\hline & Ebro & 64 & 490 & 830 & 0.59 & 260,000 \\
\hline & La Mancha & 65 & $(-)$ & $(-)$ & $(-)$ & $(-)$ \\
\hline & South Pyrenean & 66 & $(-)$ & $(-)$ & $(-)$ & $(-)$ \\
\hline & Guadalquivir & 67 & & & & \\
\hline Duero + Ebro & & & 1020 & 1380 & 0.74 & 456,000 \\
\hline
\end{tabular}

which a north-verging zone (North Pyrenean) and a south-verging one (comprising the South Pyrenean and Axial zones) can be distinguished (Muñoz, 1985). Balanced cross-sections estimate a crustal shortening ranging from $125 \mathrm{~km}$ (Vergés et al., 1995) to $147 \mathrm{~km}$ (Muñoz, 1992) in the eastern and central Pyrenees. In the westernmost segment, these values decrease by up to $80 \mathrm{~km}$ (Teixell, 1998).

The Pyrenean structures continue westwards in the Basque zone. The western part of the northern border of Iberia corresponds to the Cantabrian mountains where a basement uplift overthrusts the Duero Basin along a south-verging frontal thrust zone that can be considered as the prolongation of the South Pyrenean frontal thrust (Alonso et al., 1996). This type of deformation extends to the continental margin as well as to the north-verging structures of the continental slope (Gallastegui, 2000).
The Spanish Central System (Figs. 1, 2) is an intraplate Cenozoic thick-skin pop-up with an E-W to NE-SW main trend (De Vicente et al., 2007a, b) which is not nucleated on previous (Mesozoic) normal faults. It shows an antiformal geometry in the upper crust, with thickening in the lower crust. The deformation is asymmetric, as evidenced by the existence of a unique, large (crustal-scale) thrust at its southern border, while its northern border has a normal sequence of north verging thrusts towards the Duero Basin. At more detailed scales, different short wavelength pop-ups and pop-downs can be recognised, some of them containing Cretaceous and Cenozoic sediments; the most regular of these are found in the Gredos area (Fig. 2).

These three structural uplifts were connected by two main conjugate strike-slip deformation belts: the Vilariça Fault System to

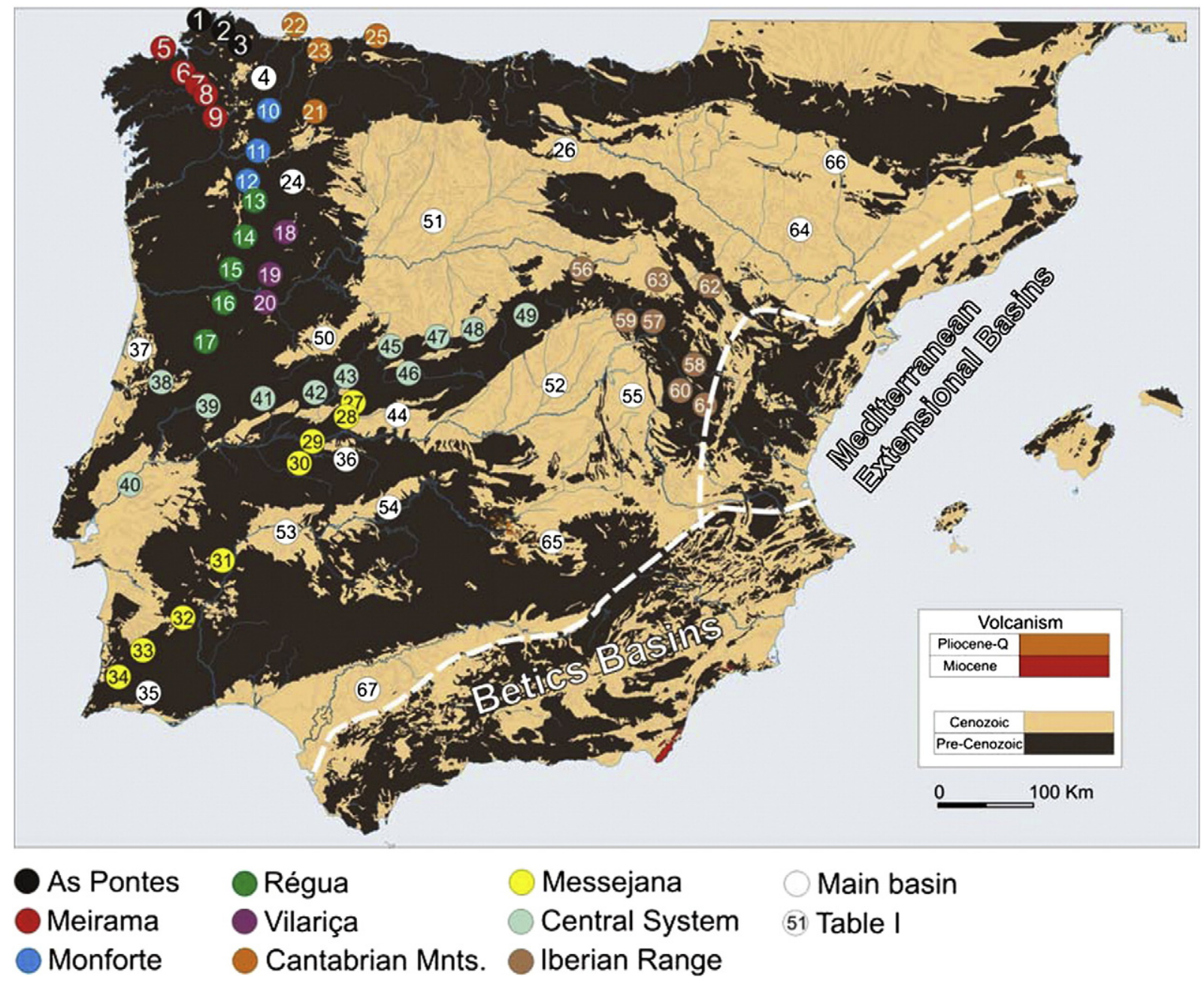

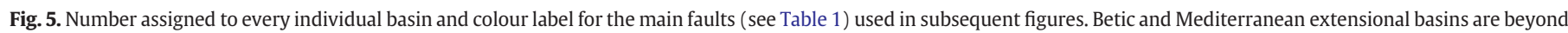
the scope of the present study. 


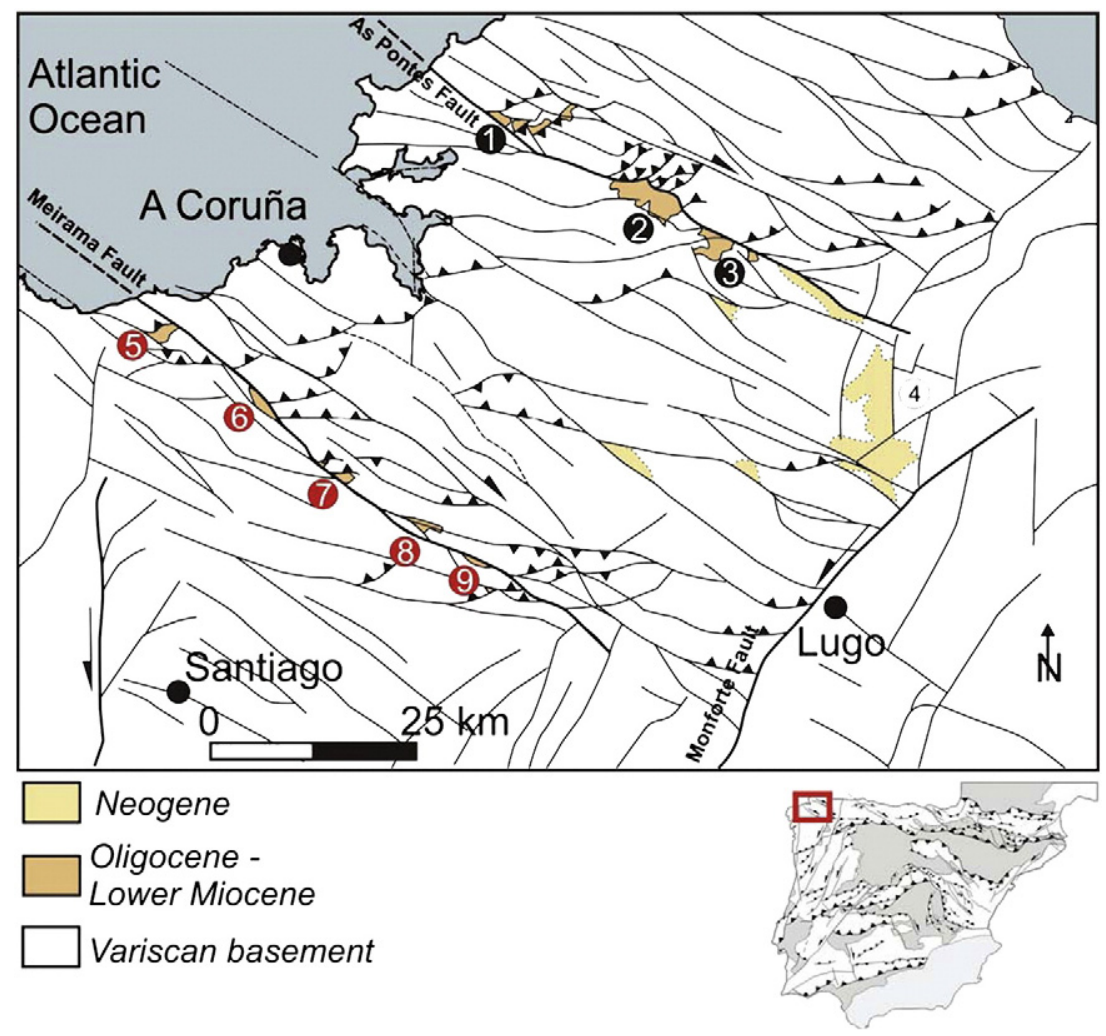

Fig. 6. Basins related to the As Pontes and Meirama faults in the NW corner of Iberia (see Fig. 5 and Table 1).

the west, and the Iberian Chain to the east (Fig. 2). The Vilariça Fault System is an intraplate NNE-SSW strike-slip deformation belt that has been active during the late Cenozoic as a result of the Iberia-Eurasia collision (Cabral, 1995; Cunha and Pereira, 2000; Vegas et al., 2004; Heredia et al., 2004). Cenozoic uplift and mountain building in the Vilariça Fault System is dominated by regional-scale, left-lateral strike-slip faults that link the Cantabrian Mountain thrusts with those of the Central System to the South, within a $200 \mathrm{~km}$ wide deformation belt that extends for more than $350 \mathrm{~km}$ in length. The resulting fault pattern is very penetrative and has a clear topographic expression. The Vilariça Fault System does not have a thrust-wedge architecture, but rather is dominated by large NNE-SSW trending left-lateral strike-slip faults and small E-W trending thrusts. These faults are linked with thrust blocks. On average, the major strike-slip fault systems are $50 \mathrm{~km}$ apart. The inter-linkage of these faults and associated splays leads to variable thrust directions, although south vergence predominates throughout the deformation belt. Nevertheless, three main faults can be mapped: from east to west, these are the Brangança-Vilariça-Manteigas, Vérin-Régua-Penacova and Monforte faults (Fig. 2).

The Iberian Chain is a wide $(200 \mathrm{~km})$ intraplate deformation belt, formed by the tectonic inversion of Permian and Mesozoic basin structures during the Cenozoic and traditionally related to the Pyrenean orogen (Álvaro et al., 1979; Guimerà et al., 2004). This structural style of basin inversion suggests mainly strike-slip displacements along NW-SE normal faults, mostly of Mesozoic age. De Vicente et al. (2009) suggested that an overall Cenozoic strain partitioning occurred with oblique compression and transpression (Fig. 2). Two main folding trends, NE-SW to E-W buckle folds and NW-SE bending folds were simultaneously developed, related respectively to basement thrusts or to positive flower structures with basement involved strike-slip faults.

The presence of a relatively thick Mesozoic sedimentary cover in the Iberian Chain provides a different tectonic style compared to the Vilariça Fault System, where the sedimentary cover is nearly absent
(Cunha and Pereira, 2000). However, the structures developed show the same kinematics and both can be interpreted as transpressional features (Fig. 3).

The easternmost part of the Iberian Chain, the Catalan Coastal Ranges, was also a left lateral strike-slip deformation belt, though in this case a later extension occurred (Guimerà, 1988).

The extensional basins of the adjacent Mediterranean border are not taken into account in this analysis since they correspond to an overprinted process related to the opening of the Valencia Trough (e.g. Janssen et al., 1993). The same situation is found for pull-apart basins in the internal Betics (e.g. Cloetingh et al., 1992) and, therefore, they are not part of the present study.

Some important NW-SE strike-slip faults, more individualized than those from the above-mentioned fault systems, include the As Pontes and Meirama faults in the NW corner of Iberia and the Ventaniella fault in the Cantabrian mountains (Fig. 2)

In particular, it should be noted that the Messejana-Plasencia fault is a high-angle left-lateral single fault which is mostly transtensional, with a very low penetrative fabric. The different morphotectonic expressions between this SW-NE fault and the SSW-NNE trending Vilariça Fault System are probably due to the presence of a Jurassic crustal-scale doleritic dike that nucleates the Messejana fault, whereas the Vilariça system is currently considered to be a lateVariscan fault zone reactivated during the late Cenozoic (Cabral, 1995). Alternatively, it could be also influenced by the faulting related to the evolution of the Atlantic passive margin during the Jurassic (Pena dos Reis et al., 2000).

The nucleation of the Cenozoic deformation in the Iberian foreland and the Pyrenees was controlled by a large variety of previous structures, since these large-scale deformation belts cross a previously stretched crust from E to $\mathrm{W}$ (the Iberian Chain and the Pyrenees), a non-extended massif (the Variscan Iberian massif, Central System and Cantabrian mountains) and the Atlantic off-shore. Its general trend appears to be controlled by the paleo-plate tectonic configuration and collision at the northern border. Nevertheless, the local nucleation 
may have been controlled by a Variscan discontinuity, by a lateVariscan granite contact, by a Stephanian-Permian fault or by a normal fault related to the Permian-Mesozoic rifting processes. In the latter cases, it could also be affected by partial or complete tectonic inversion depending on the orientation of previous normal faults (De Vicente et al., 2009).

Although N-S Cenozoic tectonic transports seem to predominate at the Pyrenees and in the Iberian foreland, the presence of a large variety of tectonic transports at local scales is ubiquitous. These include westward vergences at the Altomira range that have been explained as a process of tectonic escape (Muñoz-Martín et al., 1998). This may be a result of the constriction strain conditions of some sort present during the Cenozoic deformation of Iberia (Muñoz-Martín et al., 1998; Cunha et al., 2000; De Vicente et al., 2005a, b), leading to the simultaneous occurrence of several of these different trending deformational structures (Vergés and Fernàndez, 2006).
The Cenozoic intraplate deformation of Iberia has been related to a lithospheric folding (Cloetingh et al., 2002) that may have extended as far as the Moroccan Anti-Atlas (Teixell et al., 2003). Thus, in their lithospheric context, most of the Iberian basins can be regarded as compressional basins formed by lithospheric folding (Cloetingh and Ziegler, 2007). Crustal and lithospheric thickening has also been proposed to explain the intensive intraplate deformation of Iberia (Vergés and Fernàndez, 2006). However, numerical and analogue modelling points to some combination of both global deformation processes (Fernández-Lozano et al., 2010). It is now accepted that the entire Iberian lithosphere was regularly deformed with a close to N-S Shmax direction during the Cenozoic (Vegas, 2005, 2006). Nevertheless, since the late Miocene the $s_{h \max }$ is NW-SE orientated (Ribeiro et al., 1996; De Vicente et al., 2008a, b).

The origin of this process of crustal shortening, and related morphogenesis, must be connected to the $\mathrm{N}-\mathrm{S}$, Oligocene-late Miocene Africa-Europe convergence and to the roughly N-S $S_{\text {hmax }}$

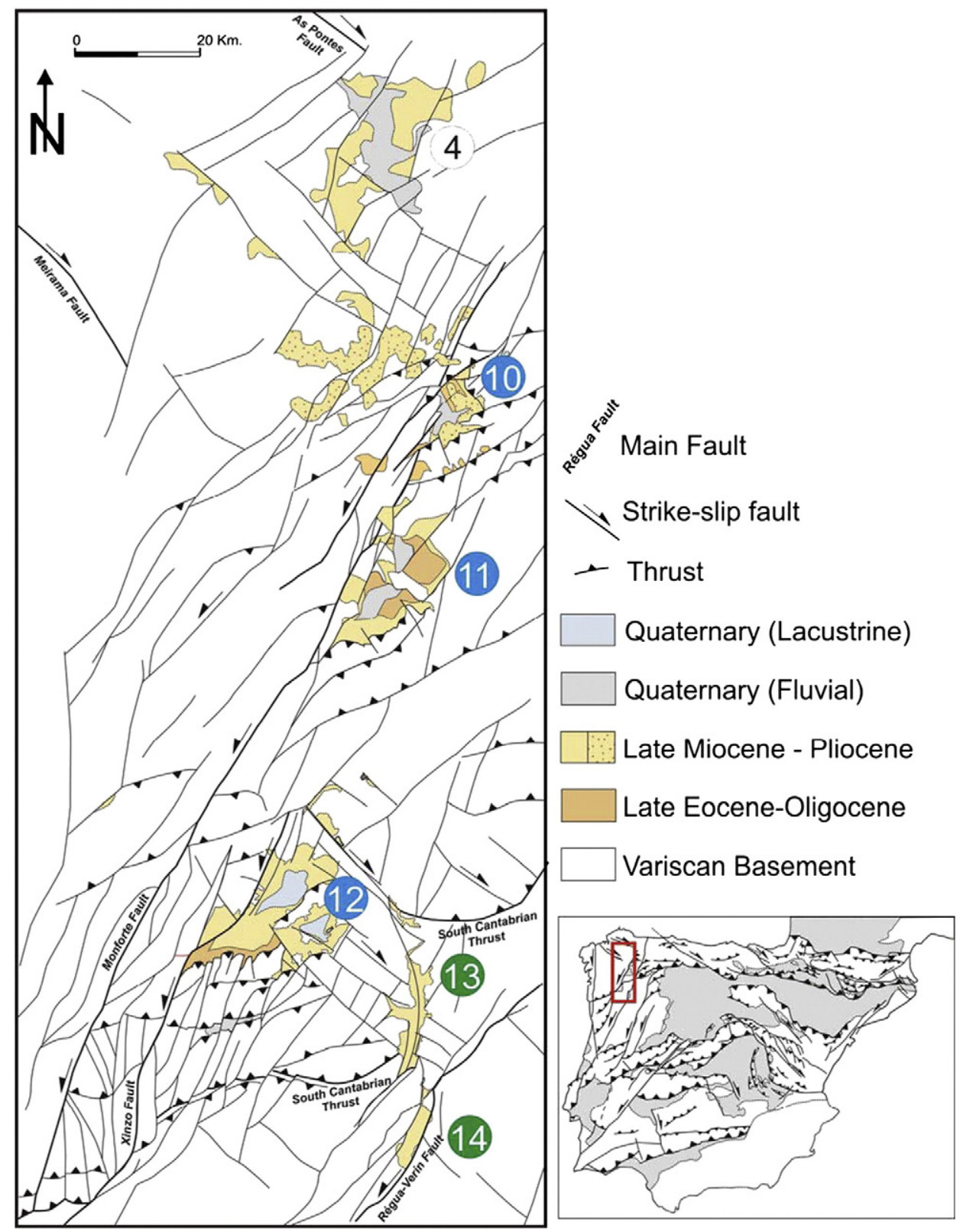

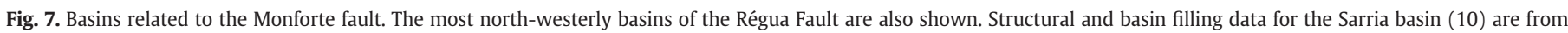
Martín-González and Heredia (2010) (See Fig. 5 and Table 1). 
transmitted stresses (Andeweg et al., 1999; Escuder-Viruete et al., 2001; De Vicente and Vegas, 2009). However, it is possible that these $\mathrm{N}-\mathrm{S} \mathrm{s}_{\text {hmax }}$ transmitted stresses already have reached significant levels in the middle Campanian (Cunha and Pena dos Reis, 1995).

The main flexural basins, which developed within the relative subsiding zones, are from north to south as follows: 1) Ebro Basin, Duero Basin and Mondego Basin; 2) Madrid Basin, Lower Tagus Basin; and 3) Guadalquivir-Algarve basin. Left-lateral NNE-SSW, NE-SW and right-lateral NW-SE strike-slip deformation belts also developed a large number of small basins (Fig. 1).

\section{Basin classification}

Within the main flexural basins, the Ebro Basin has been identified as an example of pro-foreland basin (Naylor and Sinclair, 2008). In pro-foreland basins, subsidence is concentrated in a short period of time. This occurred in the Ebro Basin during the Late Eocene as demonstrated by accelerated tectonic subsidence and high sedimentation rates (Vergés, 1999). The total amount of Cenozoic shortening in basins of this type is also larger than in a retro-foreland basin (e.g. Aquitanian Basin, see also Desegaulx et al., 1991), while intraplate deformation of the underthrusted plate (Iberia) is much more intense than to the north of the Pyrenees. Nevertheless, it is difficult to classify the Duero Basin with this criterion, since the Cantabrian mountains were initially (late Campanian to probably Maastrichtian) overthrusting the oceanic crust towards the north (Gallastegui, 2000). The main depocentres are found close to the basement uplifts (Cantabrian mountains and the Central System) rather than in the centre of the basin. This situation is also true for the Madrid Basin. Nevertheless, large lake systems were developed at the centre of basins whose

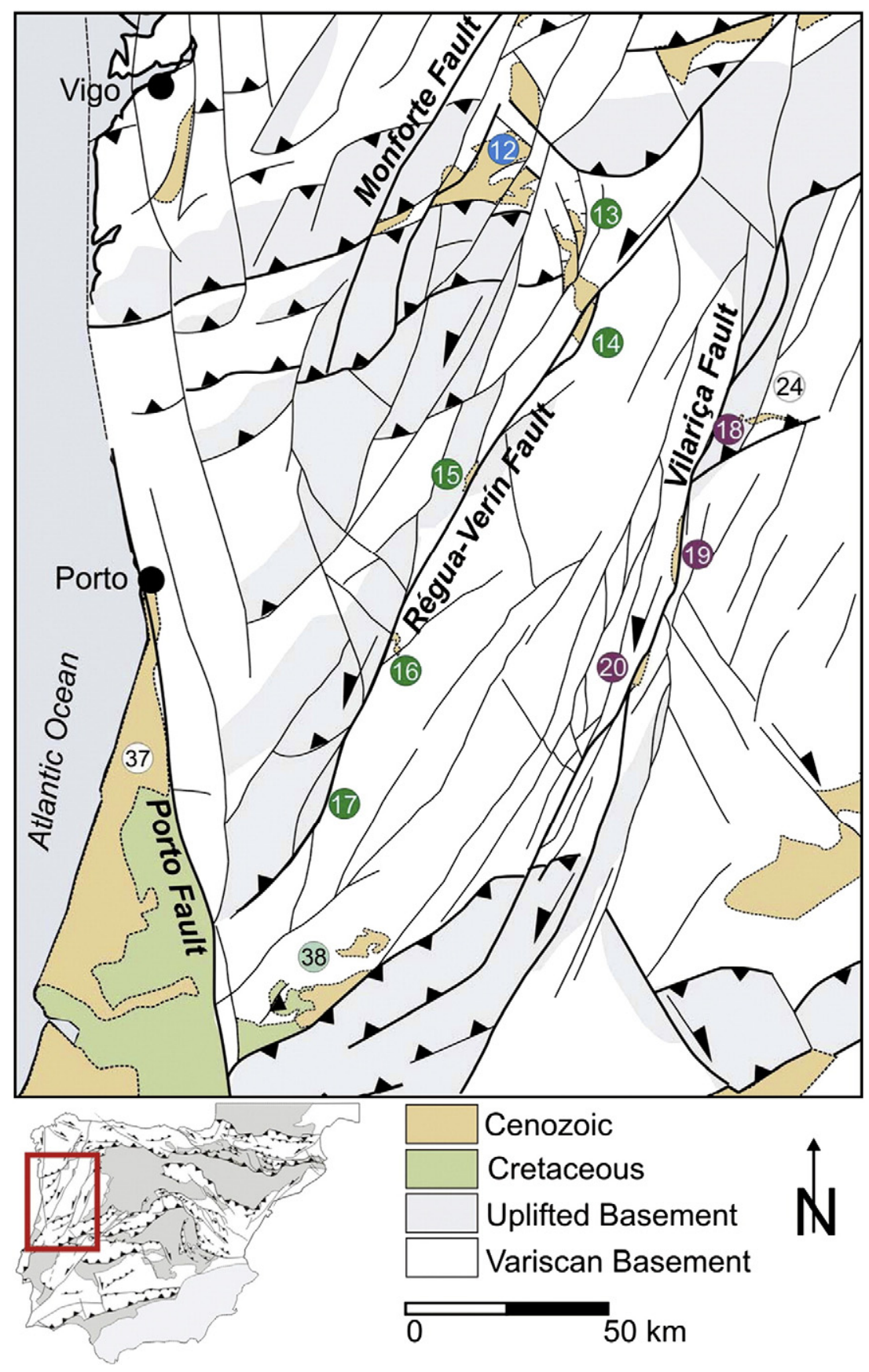

Fig. 8. Tectonic map of the Vilariça and Régua faults and related basins (see Fig. 5 and Table 1). 
depocentres migrated to the East during the Cenozoic (Anadón et al., 1989).

Strike-slip related basins have been defined in several seminal papers (e.g. Tchalenko and Ambraseys, 1970; Crowell, 1974; Biddle and Christie-Blick, 1985). According to Cunningham (2005), in the strike-slip related basins this kind of deformation belts can be defined as intracontinental intraplate transpressional orogens. The structural and basinal elements in such deformation belts are complex and a variety of intramontane and range-flanking basins can develop. These basins can be classified as ramp basins, half-ramp basins, open-sided thrust basins, pull-apart basins, and strike-slip basins. A more recent compilation of the possible tectonic structures related to strike-slip faulting can also be found in Cunningham and Mann (2007). The Iberian foreland basins are generally filled with coarse siliciclastic facies (e.g. alluvial fans) adjacent to lacustrine facies. In this paper, we will use a basin classification as summarised in Fig. 4 .

\section{Iberian intramontane foreland basins of Cenozoic age}

A large number of intramontane basins developed within and at the borders of these basement uplifts and strike-slip deformation belts. Excluding the extensional basins, more than sixty basins can be mapped. We have assigned a number to each individual basin and a colour label for the main faults that will be used in all the figures (see Table 1 and Fig. 5).

The As Pontes and Meirama faults (Fig. 6) are Cenozoic right-lateral strike-slip faults that give rise to 8 transpressive basins: Cantarallana, As Pontes, Roupar, Laracha, Meirama, Visantoña, Xanceda and
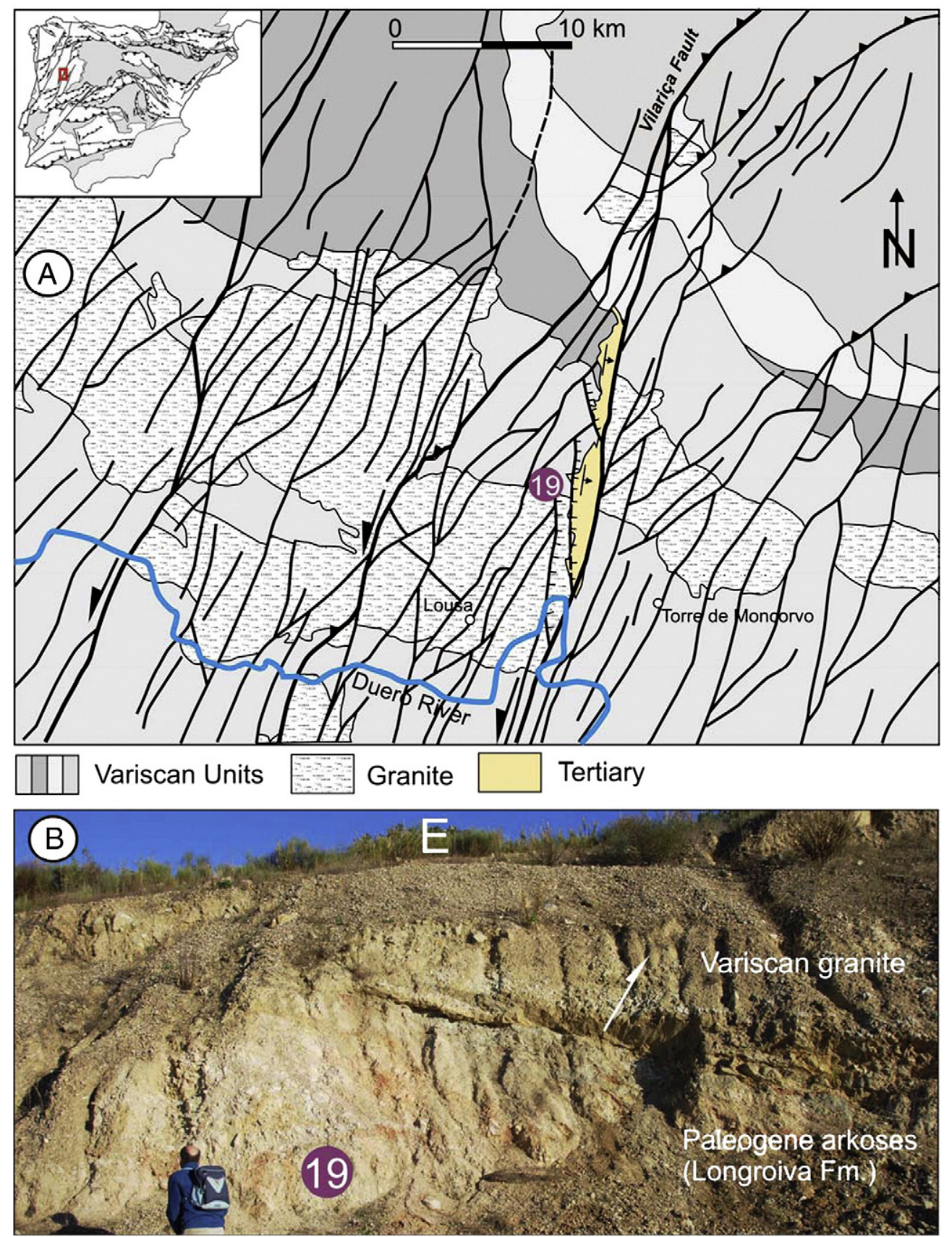

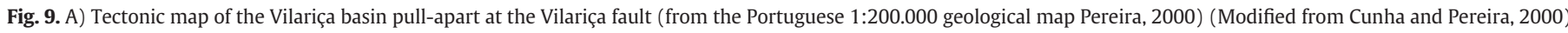

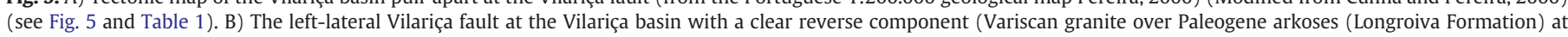
Vilariça (Portugal). 

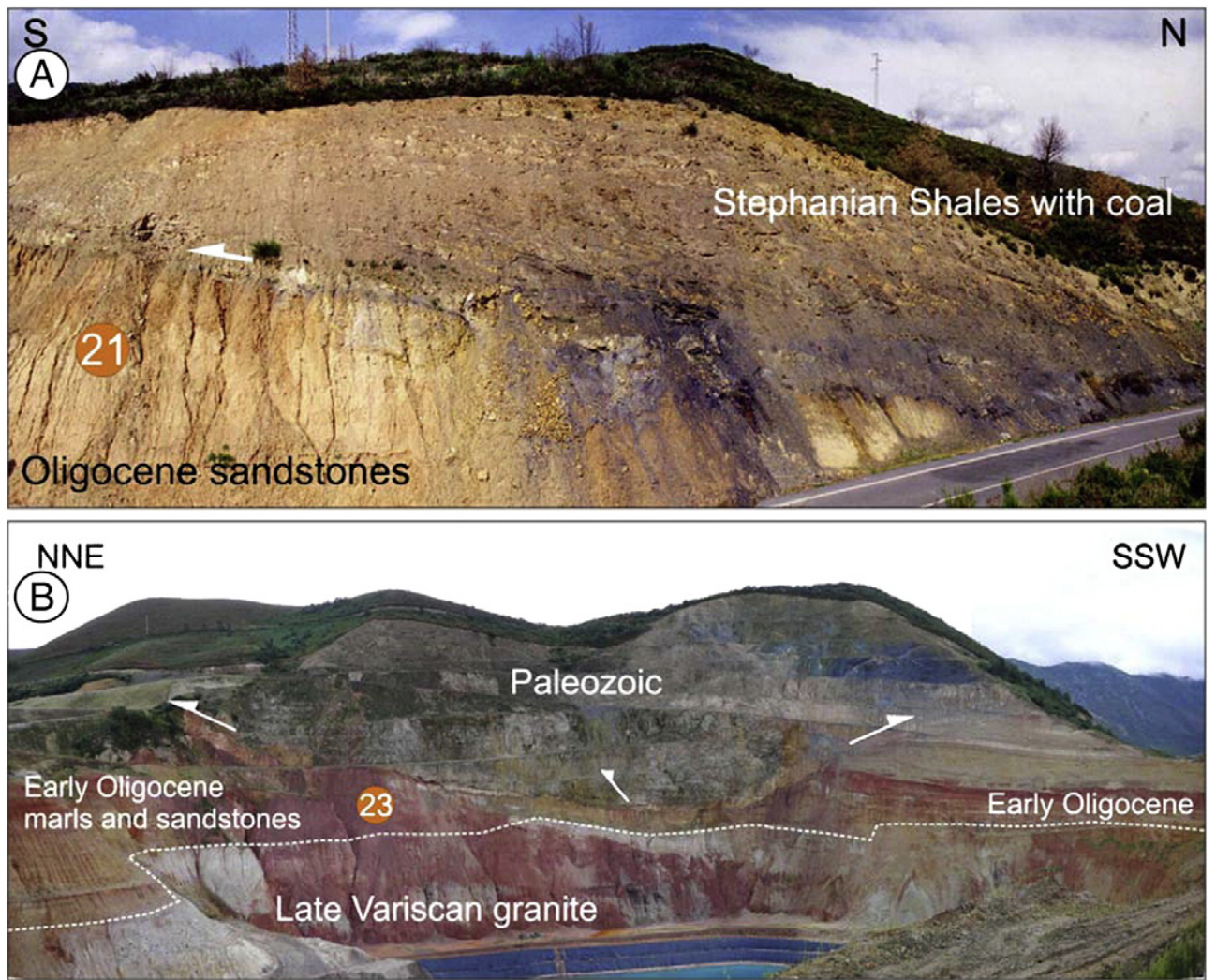

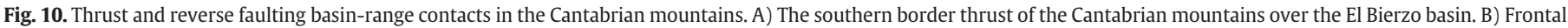
view of the Boinás thrust over the Narcea basin (Cantabrian mountains). Boinás gold mine.

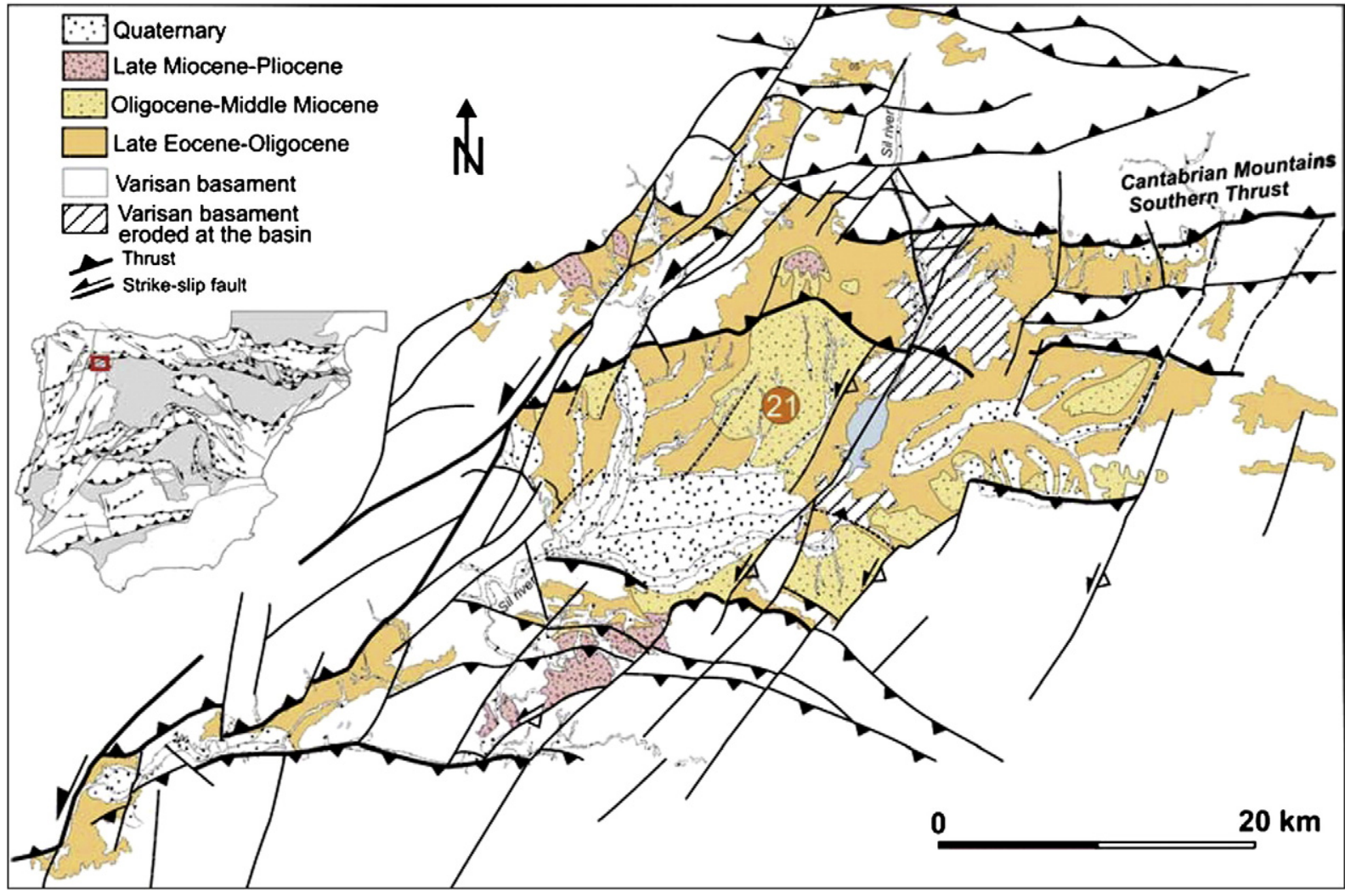

Fig. 11. Tectonic map of the El Bierzo basin. Basin filling data are from Martín-González and Heredia (2010) (see Fig. 5 and Table 1). 


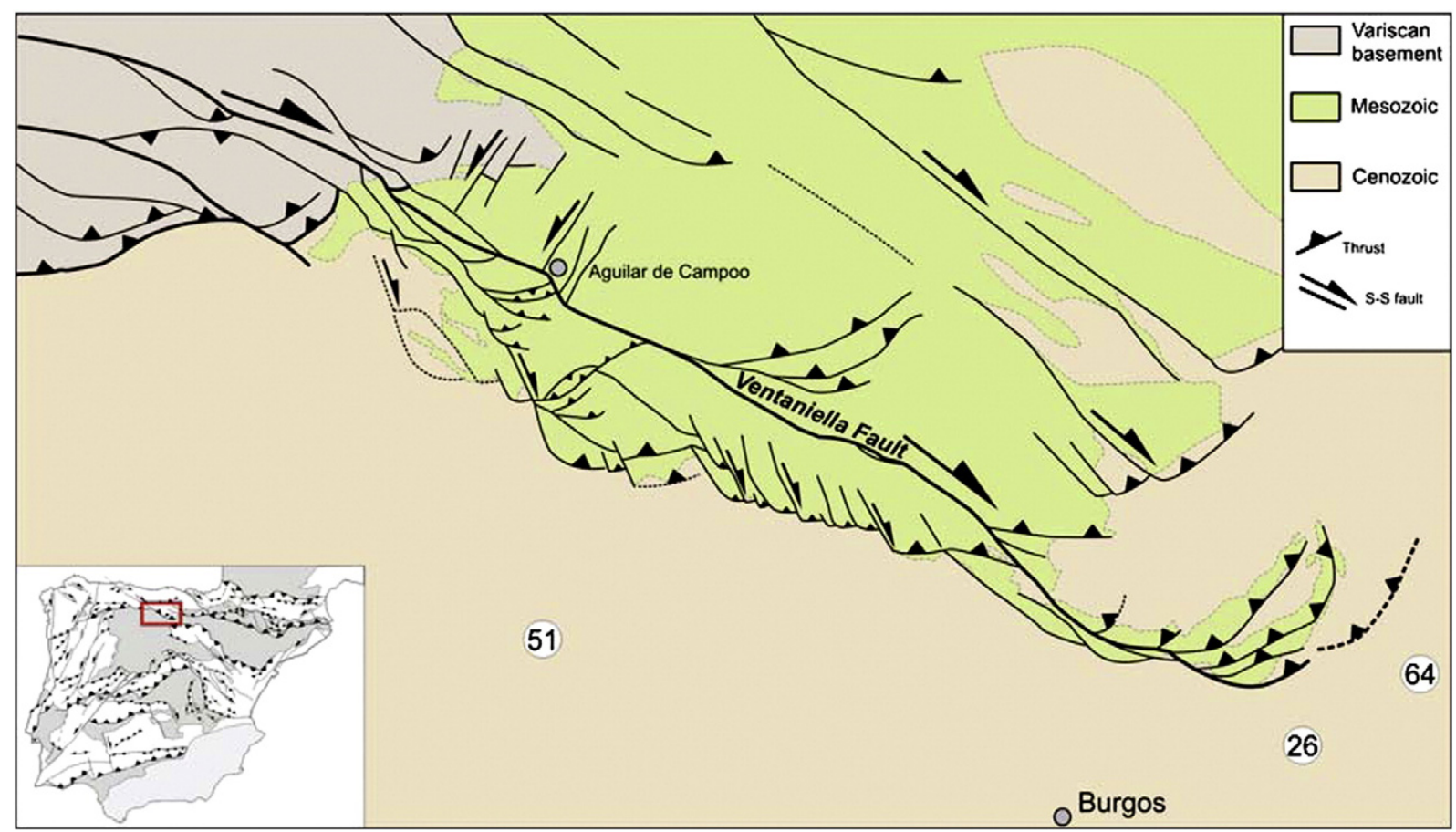

Fig. 12. Tectonic map of the SE termination of the Ventaniella fault at the Cantabrian mountains. Ebro-Duero basins contact (see Fig. 5 and Table 1 ).

Boimorto (Santanach, 1994). Although the geological knowledge of every individual basin in Iberia is very heterogeneous, the As Pontes basin is an exceptional natural laboratory for improving our understanding of the origin and evolution of restraining bends, since its economic value has led to it being almost completely dug out
(Santanach et al., 2005). The Vilalba basin seems to have a different structure since it is comprised of only Late Miocene sediments, while the related faults are roughly $\mathrm{N}-\mathrm{S}$ orientated (probably normal faults). They may form a kind of horsetail splay of the southeast termination of the As Pontes fault.
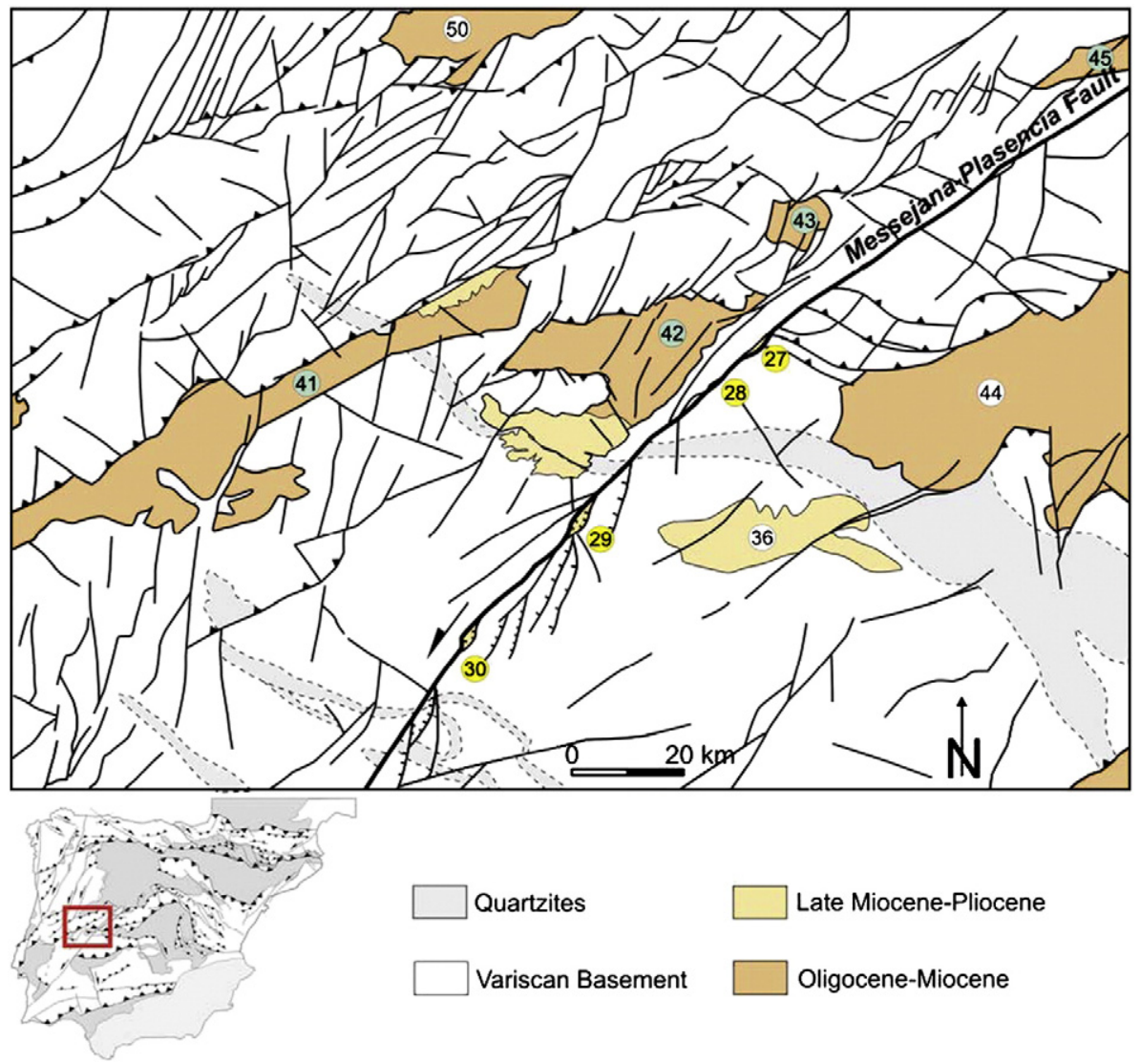

Fig. 13. Basins related to the NE Messejana (Plasencia) fault. Central basins of the Central system are also shown (see Fig. 5 and Table 1 ). 
The Monforte fault (De Vicente and Vegas, 2009) has a very distinct layout at the south, but is more blurred to the north (Fig. 7). The course of the Xinzo fault is roughly parallel to this fault, and both are left-lateral strike-slip faults. This fault system is transferring the South Cantabrian thrust towards the south. There are three relatively large basins immediately to the east of the Monforte fault: Xinzo de Limia, Monforte de Lemos and Sarria basins. The Xinzo basin is the only one of the basins considered that was still partially endorheic until it was dried out during the last century.

Several basins can be considered as forming part of the Vilariça Fault System, such as the Longroiva and Vilariça basins (Fig. 8). The Verín, Chaves, Vila Real, Besteiros and Mortágua basins lie along the Vérin-Régua-Penacova fault. The Verín basin has been defined as being related to the NW termination of the Régua fault in the form of an extensional horsetail splay (De Vicente and Vegas, 2009), whereas the Chaves basin is a narrow, but sharp releasing bend (Fig. 8). There is a general tendency for basin narrowing towards the east, with the narrowest ones located at the Vilariça fault, where the Vilariça (Fig. 9) and Longroiva basins are fairly good examples of gentle releasing bends (Cabral, 1989; Cunha and Pereira, 2000) across a positive flower structure to the east (Fig. 7B). The horizontal displacement of the previous Variscan granite is about $8 \mathrm{~km}$ (Cabral, 1989). Registered seismicity and geomorphological evidences point to significant Late Miocene to Quaternary tectonic activity in the region (Cunha, 1987, 1992; Cabral and Ribeiro, 1990; Sequeira et al., 1997; Cunha et al., 2000; De Vicente et al., 2008a, b; Martín-González, 2009).

Within the Cantabrian mountains, the Alpine N-S shortening is overprining a late Variscan deformation with a similar $s_{\mathrm{hmax}}$. Nevertheless, the present topography has developed over E-W narrow pop-ups and pop-downs that locally overthrust Cretaceous or Cenozoic sediments (Alonso et al., 1996; De Vicente et al., 2007b)
(Fig. 10). The El Bierzo Basin has been interpreted in terms of an interference between the cross-cutting faults of the Vilariça system and the South Cantabrian thrust (Fig. 11) (De Vicente and Vegas, 2009), with a predominance of segmented pop-downs to the east and elongated bends to the west, where the NNE-SSW strike-slip faults prevail. Recent tectono-stratigraphic analysis of the basin filling indicates that the main deformation episode was post-Early Oligocene to Pliocene (Martín-González and Heredia, 2010).

The Ventaniella fault separates the Cantabrian mountains to the west from the Basque mountains to the east. This ancient rift border fault was active during the Permian and the Triassic extensional processes, giving rise to a thick Mesozoic stratigraphic succession to the east (Fig. 12). At the time of the Cenozoic contraction, it moved as a right-lateral strike-slip fault with a well structured contractive horsetail splay in the northern block of its SE termination (Bureba Basin) (De Vicente et al., 2008b), which also constitutes the limit between the Duero and Ebro basins. The Ventaniella fault has also an important reverse component with vergence to the SW (Marín et al., 1995). Towards the NW, the Ventaniella fault interferes with a narrow E-W pop-down to form the Oviedo basin (Alonso et al., 1996), which also has some splay-like structures.

Along the Messejana (Alentejo-Plasencia) left-lateral strike-slip fault (Fig. 13) there is a series of small pull-apart basins that contain Miocene near-source alluvial records: Plasencia, Moro, Cañaveral and Ribera de Araya (Villamor, 2002). The horizontal displacements are about 1.5 and $3.5 \mathrm{~km}$ since probably early Miocene (Villamor, 2002). Its main trend is NE-SW, giving a very smooth shape; the pull-apart basins are concentrated at the centre, where the fault becomes slightly more NNE-SSW oriented. This part of the Iberia deformed foreland is clearly partitioned into low-angle thrusts at east and west (Central System, Ponsul) and a high-angle left-lateral single fault (transtensional): the Messejana fault (Fig. 13).

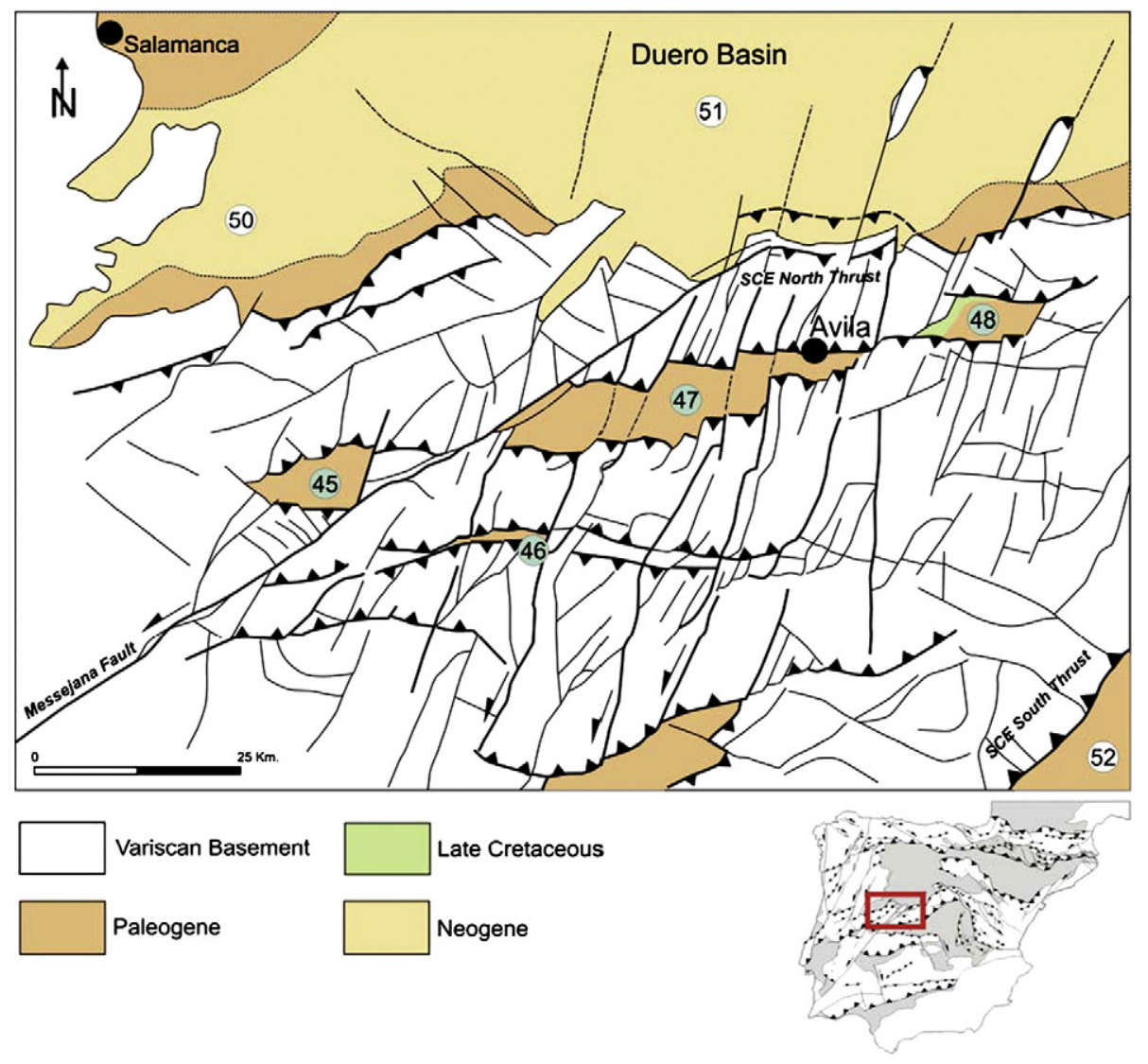

Fig. 14. Central system pop-downs (Gredos) (De Vicente et al., 2007) (see Fig. 5 and Table 1). 


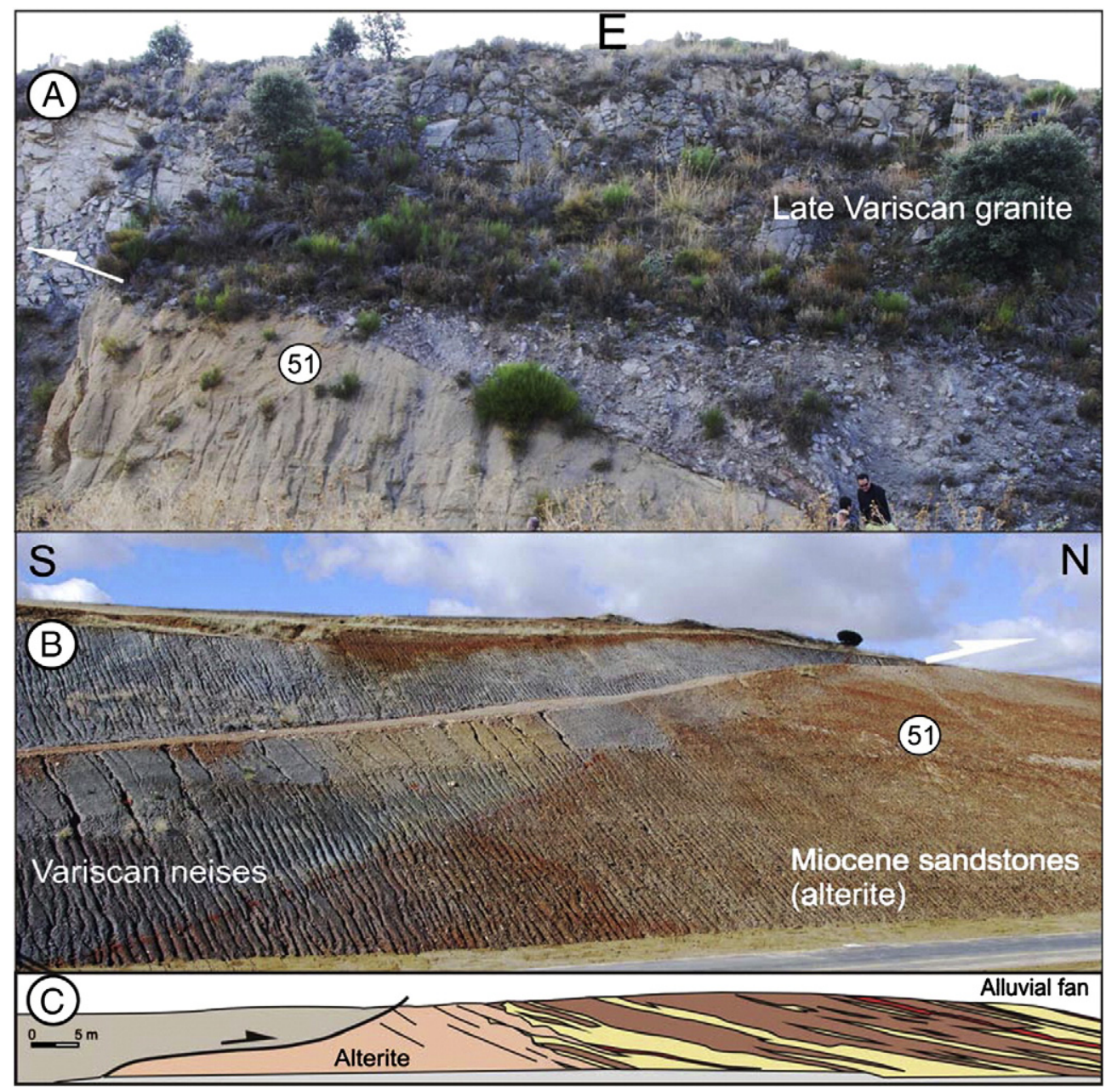

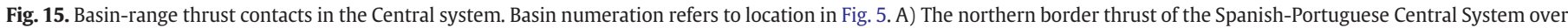
the Duero Basin at Cardeñosa (Ávila); B) Avila-Salamanca highway and C) Cross section visible at the highway borders.

Pop-down and segmented pop-down basins developed within the Spanish Central System. The contacts between the strike-slip faults (mainly NNE-SSW left-lateral faults) and thrusts are usually very sharp (Corneja, Cepeda, Amblés and Coria basins) (Fig. 14). A different configuration can be found in the easternmost pop-down of the Central System at the Lozoya basin. Here, the fault geometry forms a gently shaped pop-down. This probably is the result of the different natures of the Variscan basement, which is more granitic to the west and composed of larger amounts of metamorphic rocks to the east. In any case, thrust dips are very low independently of the type of rock affecting the hanging-wall (Fig. 15). An important decrease in deposit thickness is observed between the Madrid Basin and the intramontane basins of the interior of the Central System, not only for the syntectonic sediments but also for the Paleocene and Eocene (e.g. LópezOlmedo et al., 2005).

Tectonic activity was highest during the Oligocene and decreased during the early Miocene. During the late Miocene and Pliocene, some structures underwent tectonic rejuvenation (Pereira, 2000; De Bruijne, 2001; De Bruijne and Andriessen, 2002). However, the westernmost areas show continuous activity until the present (Cabral and Ribeiro, 1990; Sequeira et al., 1997; Ferreira-Soares et al., 2005).

Within the Iberian Chain, small basins are located in the E-W restraining bends of the NW-SE right-lateral strike-slip faults (and folds), such as the Zaorejas and Piqueras basins (Fig. 16). Longitudinal basins along the NW-SE strike-slip faults appear in synclines between positive flower structures (e.g. Alcorón, Alto Tajo and Cabriel basins) with clear reverse components (Fig. 17).

\section{Sedimentary infilling}

Broadly speaking, the sedimentary records of the main Cenozoic basins of Iberia are relatively well known but their temporal framework has not been very well constrained (e.g. Calvo et al., 1993; Alonso-Zarza, 2008; Herrero et al., 2010) (Fig. 18). Nevertheless, the main basins (e.g. Ebro, Duero, and Madrid) have been studied much more intensely. However, an analysis of the sedimentary infilling of the Iberian Cenozoic basins allows us to deduce that to a large extent they share a common evolution. The total thickness of continental sediments since the Paleocene is over $5000 \mathrm{~m}$ in the Ebro Basin, $2500 \mathrm{~m}$ in the Duero Basin, $3500 \mathrm{~m}$ in the Madrid Basin and $1100 \mathrm{~m}$ in the Lower Tagus Basin. Some basins partially disconnected from the main ones also show significant sediment thickness; for instance, the Loranca (Madrid) basin and Montalban-Daroca-Calatayud (Ebro) basin, where syntectonic Eocene to Lower Miocene deposits accumulated a thickness of about 2000 m (Casas et al., 2000; Alcalá et al., 2000).

Growth strata related to syntectonic deposits are common at the margins of the Ebro, Duero and Madrid basins. In the Ebro Basin growth strata accumulation has persisted for about $31 \mathrm{Ma}$ (marine 57-37 Ma and continental 37-25 Ma) (Vergés et al., 2002).

Tectonic subsidence analysis allows a quantitative assessment of accommodation space evolution. In this paper we have therefore compiled existing results on subsidence analysis of the Ebro Basin (Vergés et al., 1998) and the fringes of the Iberian Range (Van Wees et al., 1998; De Vicente et al., 2009), but also expanded these with 


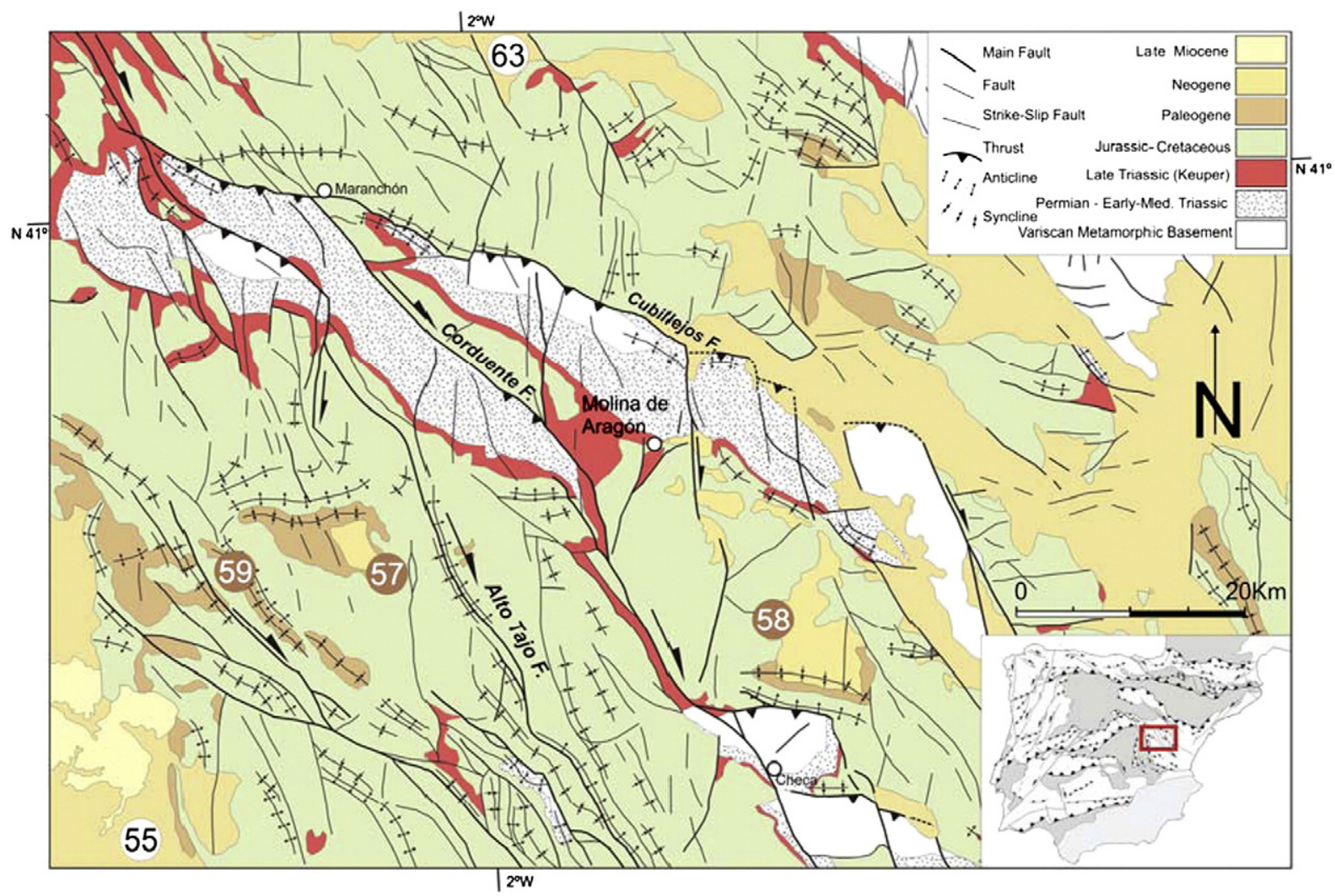

Fig. 16. Tectonic map of the Castilian branch of the Iberian range and related basins (Modified from De Vicente et al., 2009) (see Figs. 3, 5 and Table 1).

results from backstripping in the Madrid and Duero basins from well data (Lanaja, 1986; Querol, 1989) and stratigraphic sections (De Bruijne, 2004; Torres et al., 2006; Santanach et al., 2005). In our analysis the effects of paleo-water depth and paleo-topography are excluded, since water depths were not greater than a few tens of meters (Calvo, 2004). The results are shown in Fig. 19 (separately for the main flexural basins and the small pop-downs and strike-slip related basins), alongside common features in the sedimentary filling of the Iberian Cenozoic basins compiled by Calvo et al. (1993) and Calvo (2004). The general trends are summarised in four stages as follows, and generally agree well with phases in the evolution of the accommodation space illustrated by the subsidence analysis:

1) The first major paleogeographic change occurred at the transition from Early to Middle Eocene, with the opening of a large number of Cenozoic basins. Very thick sedimentary sequences started to accumulate at this time, with higher sedimentation rates at the northern border of the Pyrenean foreland (Duero westwards, Ebro eastwards). The Duero and Madrid basins began to separate into individual basins. The most important subsidence peak took place in the Ebro Basin between 55 and $35 \mathrm{Ma}$, but continued subsidence since the Late Cretaceous is recorded in the northern and eastern sectors of the Madrid Basin and also in the SW part of the Duero Basin (Santisteban et al., 1991).

In contrast, the basins related to strike-slip faulting have an extremely varied record regarding thickness (in general low) and time (Paleogene or Neogene). The beginning of sedimentation is therefore diachronic. Coarse clastic alluvial fan deposits and distal lacustrine facies predominate.

2) During the Oligocene-Early Miocene (34-16 Ma), sedimentary basin filling was in general characterised by the development of several tectono-stratigraphic units, separated by breaks in the sedimentation (Calvo et al., 1993; De Vicente et al., 2007a, b). Although, at smaller scales, the number and the specific ages of these units vary from one basin to another, indicating more local activity at different range borders, the main point is that the largest number of breaks in the sedimentation was concentrated over this time span. This set of sedimentary units can thus be interpreted to be syn-tectonic. The most important subsidence therefore developed during the Oligocene in basins with very different tectonic settings: Albarracín basin, eastern Madrid Basin, As Pontes basin, Loranca basin, $\mathrm{N}$ and centre Madrid Basin and slightly later, the Duero Basin. The large number of breaks in the sedimentation found during the Early Miocene can be related to a deceleration of tectonic subsidence.

From the late Oligocene, wide saline lake systems developed, which indicates that the saline materials of the Mesozoic and of the Paleogene had already been tectonically uplifted, then eroded and later deposited in endorheic settings.

3) During the Early to Middle Miocene, continuous tectonic activity in the ranges gave rise to high sedimentary load-subsidence ratios with wide expansion of the lake systems, which were firstly infilled with dominant evaporites and later with carbonates. This context indicates the existence of a previous important relief which was being rapidly eroded.

The Miocene of many basins can be divided into three units limited by major breaks in the sedimentation (Calvo, 2004): the lower Ramblian-Aragonian (early to middle Miocene), Lower Aragonian-Upper Vallesian (middle to late Miocene) and Upper Vallesian-Turolian (late Miocene to early Zanclean). Subsidence continued in the Duero and Madrid basins, but at a low rate, whereas it terminated in the Iberian Chain basins.

4) Towards $\sim 9.5 \mathrm{Ma}$ (Upper Vallesian, middle Tortonian) a very important paleogeographic change occurred in all of these basins. An important discontinuity is found separating stratigraphic successions deposited in well differentiated paleogeographic settings. At this time, a change from endorheic to exorheic regime took place in several basins (Cunha et al., 1993, 2000; Calvo, 2004). 

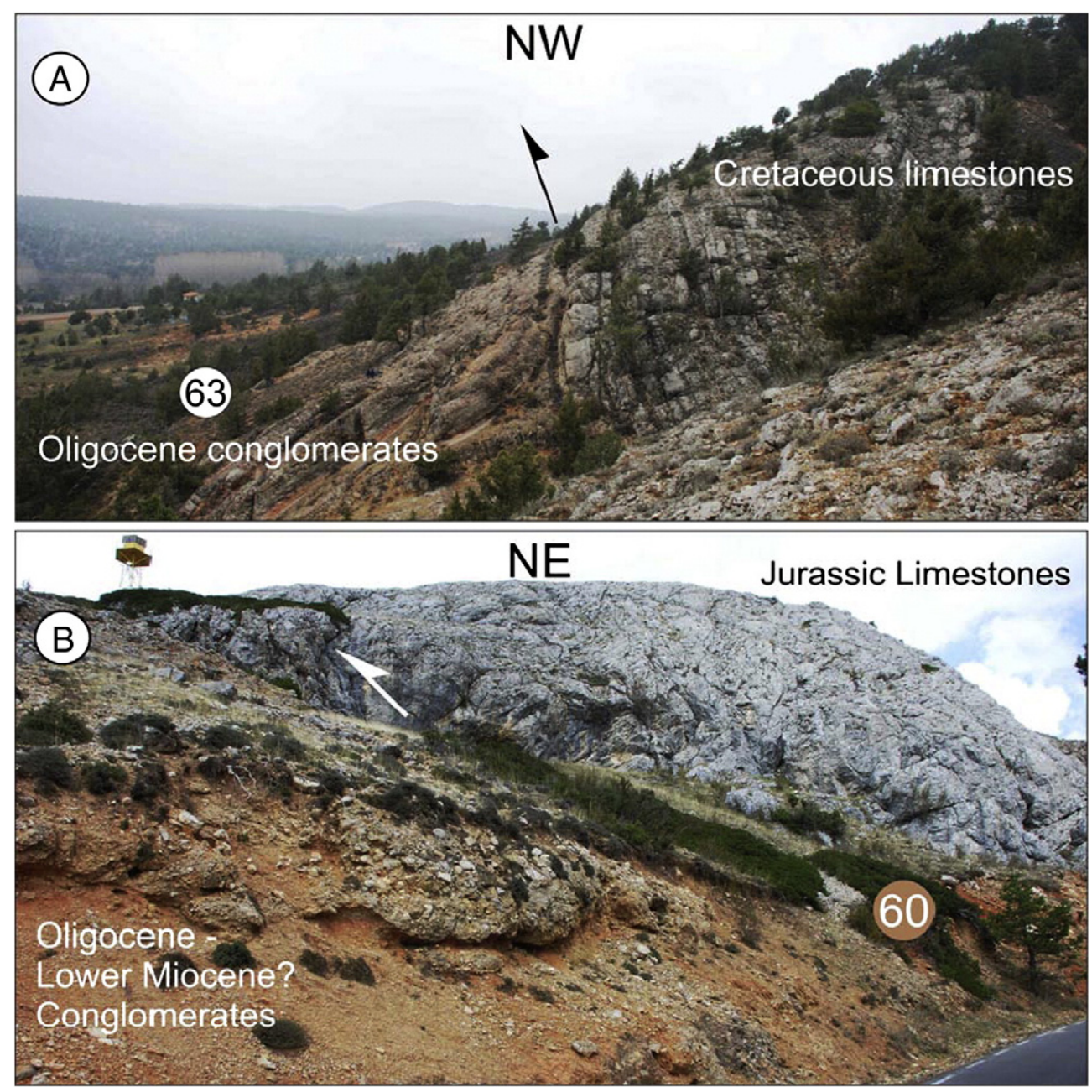

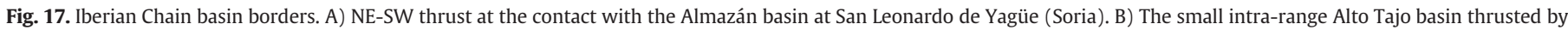
strike-slip related faults (interpreted as basins between positive flower structures). El Portillo pass (1790 m) at Guadalaviar (Teruel).

In the Portuguese basins, from north to south (e.g. Cunha, 1992; Cunha et al., 2000; Lopes and Cunha, 2007) several main breaks in the sedimentation were identified and dated as follows: middle Campanian ( $\sim 80 \mathrm{Ma}$ ), early Lutetian ( 48 Ma), middle Oligocene ( 28 Ma), late Burdigalian (17 Ma), middle Tortonian ( 9.5 Ma), middle Messinian $(\sim 6 \mathrm{Ma})$ and latest Zanclean $(\sim 3.7 \mathrm{Ma})$. The drastic paleogeographic change during middle Tortonian reflects a large-scale tectonic event induced by the climax of compression in the western part of the Central System. During the late Miocene and Zanclean the sedimentation was endorheic and consisted of alluvial fans along the active faults (Cunha, $1996,1999)$. The general change from sedimentary infill to fluvial incision occurring at the end of the Gelasian could be the result of the position of sea-level, which was much lower than during the Pliocene (about 40 to $60 \mathrm{~m}$ above the present sea-level), with sea-level change being unable to compensate for the continuing regional uplift.

As regards the Portuguese mainland, incision rates of 0.05 to $0.13 \mathrm{~mm} / \mathrm{yr}$ have been estimated for the last 2.6 Ma (Cunha et al., 2005, 2008; Martins et al., 2009); for the coastal region, an average uplift rate of around $0.1 \mathrm{~mm} / \mathrm{yr}$ since the Piacenzian was estimated (Cabral et al., 2007). Geological studies of the Late Pleistocene coastal deposits in Galicia (NW Spain) and their comparison with the raised beaches located in the central part of the northern Spanish coast
(Cantabria) also show that the Cantabrian sector has been uplifted 2$3 \mathrm{~m}$ more than the northwest coast since the Last Interglacial (Monino Sáez et al., 1988; Alonso and Pagés, 2007).

Low subsidence rates are found in some Iberian basins for this period, mainly in those related to locally thick (less than $100 \mathrm{~m}$ ) late Cenozoic alluvial fan sediments as in the northern areas of the Madrid, Moraleja and Badajoz basins.

The main breaks in the sedimentation and changes in the evolutionary pattern of the filling of the Cenozoic basins of Iberia appear to reflect changes in the plate dynamics, and the effective transmission of the tectonic stresses from the active border towards the interior of Iberia. To assess this model, we have plotted from west (Lower Tagus Basin) to east (Ebro Basin) the Cenozoic sedimentary record of five Iberian basins (including Duero, Madrid and Ebro basins) with their main filling breaks and the moments of basin initiation (Fig. 20). The first stage (45-50 Ma) coincides with the beginning of the sedimentary record in the foreland and intraplate deformation in the main basins. This Early Eocene sedimentary-tectonic activity must be related to the North Iberian (Cantabrian-Pyrenean) border. However, it is interesting to note that this event can be found even as far south as the Algarve offshore (Lopes et al., 2006). 

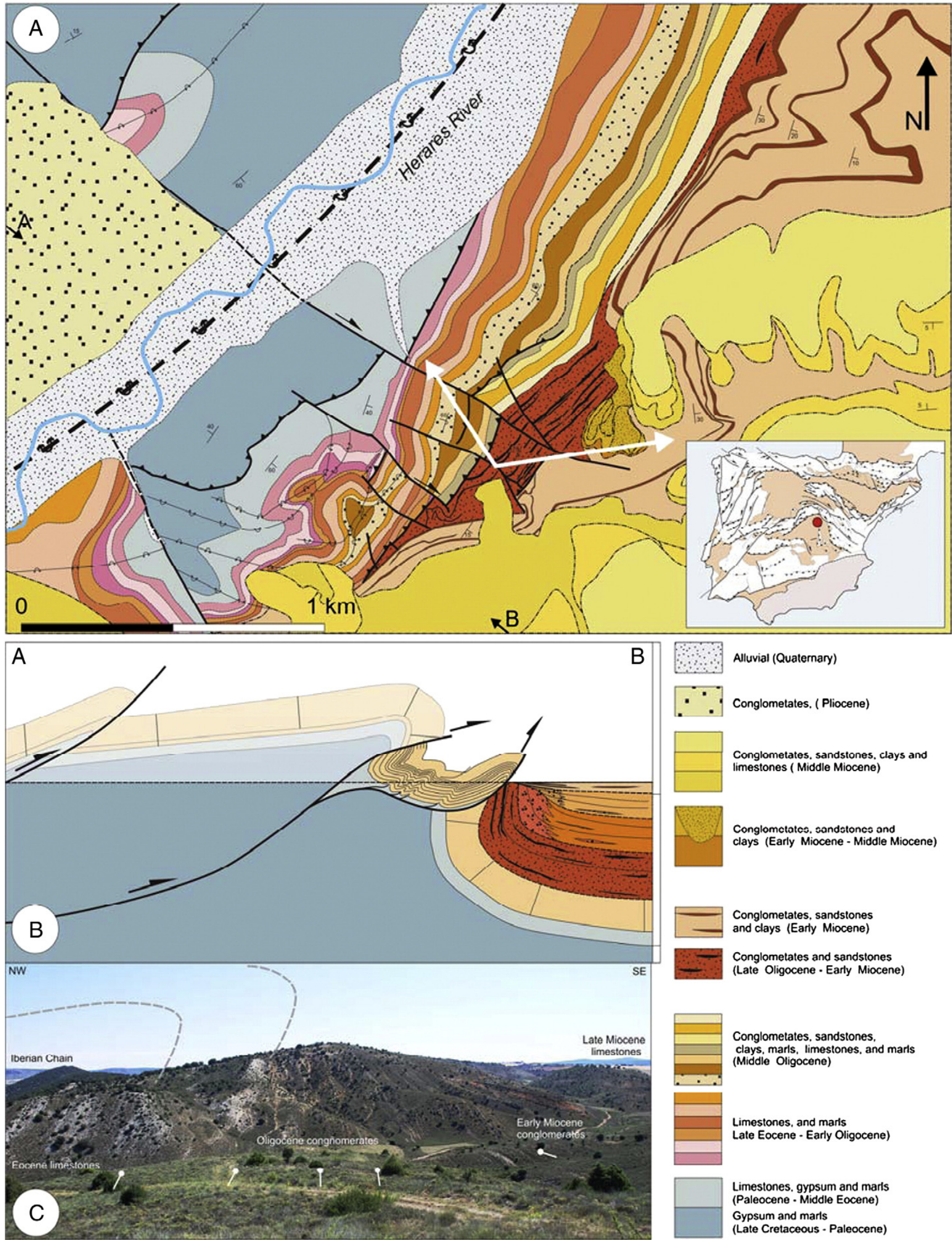

Conglometates, sandstones,

clays, marls, limestones, and marts (Middle Oligocene)

Limestones, and maris

Late Eocene - Early Oligocene)

Limestones. gypsum and marls (Paleocene-Middle Eocene)

Gypsum and marls

(Late Cretaceous-Paleocene) 

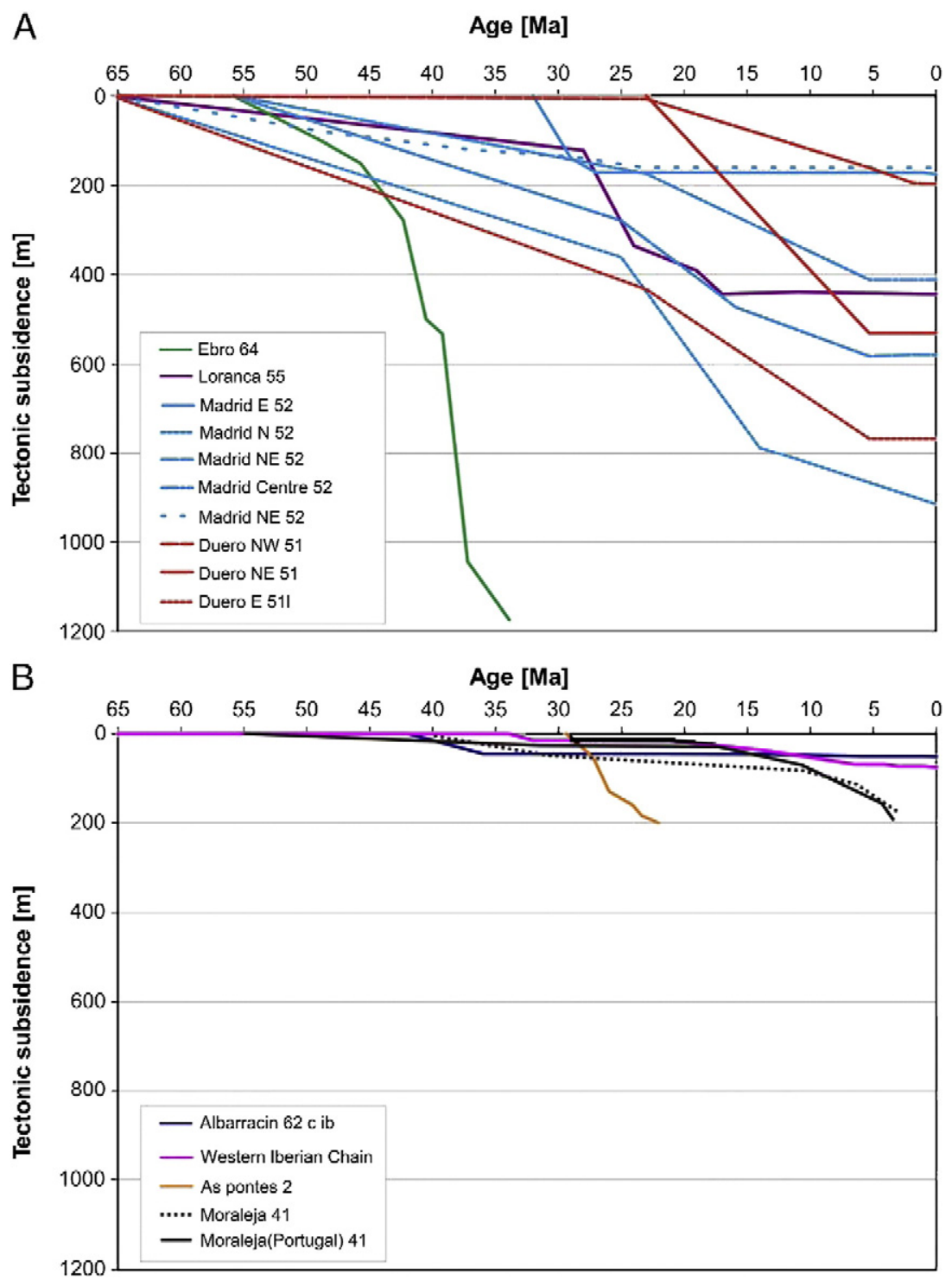

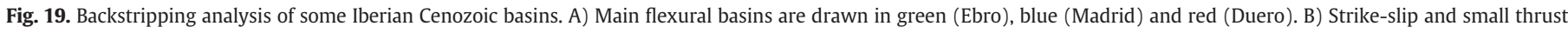

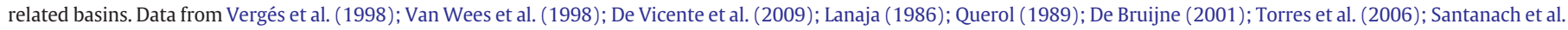
(2005) and Calvo et al. (1993) (see Fig. 5 and Table 1).

Nevertheless, the largest number of breaks in sedimentation occurred over the 30 to $15 \mathrm{Ma}$ time span, with the relative maximum around the Oligocene-Miocene transition (22 Ma). There is an overall decline in sedimentary events between 15 and $10 \mathrm{Ma}$, when the most important paleogeographic tectonic features of the Iberian interior were already formed.

A new stage in this common evolution is found for the last 9.5 Ma, coinciding with the change from endorheism to exorheism in the majority of the Spanish basins (except in the NE part of the Xinzo basin). This important paleogeographic change was not accompanied by new basin formation, as in previous stages, which may point to very large-scale processes involving the entire Iberian plate such as a general uplift.

There are some differences between the Cenozoic sedimentary evolution of western and eastern Iberia (with the limit at the Madrid Basin) (Fig. 20). Although the results show the same general tendencies, a slightly higher activity eastwards can be observed at the beginning of the process, and more intense recent activity westwards. This is in agreement with the westward temporal shift at the onset of accelerated subsidence.

\section{Basin size distribution}

Most of the topographic features are scale invariants. In many cases, they are the result of different tectonic/erosion-coupled processes, which also occurred at different times. In a broad sense, however, topographic characteristics are related to the dynamics that existed during the last few million years (10-20 Ma). The size distribution of geographical objects (islands and lakes) fits a power law such as $\mathrm{N}=\mathrm{C} / \mathrm{r}^{\mathrm{D}}$, where $\mathrm{D}$ is the fractal dimension (Turcotte, 1997). It should be noted that this type of relationship is also found in objects with a more geological character. For instance, it is found between the earthquake rupture area and the number of seisms in a certain zone (Gutenberg-Richter Law), and more recently for the size distribution of tectonic plates (Bird, 2003).

The Cenozoic tectonics of the Iberian Peninsula built a number of basins and ranges that seem to follow some kind of power-law size distribution. In previous work (De Vicente et al., 2005b), we have used the SRTM database with a $90 \mathrm{~m}$ pixel to carry out an analysis of the size distributions of fifty five Cenozoic basins of the Iberian foreland with areas over $20 \mathrm{~km}^{2}$ (characteristic lengths, $\mathrm{A}^{1 / 2}, 293$ and $4.5 \mathrm{~km}$ ). 
This analysis detected a fractal dimension (D) of 0.48 in a range between 100 and $20,000 \mathrm{~km}^{2}$ (Fig. 21). In addition, a better fractal distribution is found if the Ebro and Duero basins are considered as a single basin, lending weight to the idea that the joint Duero-Ebro Basin should be considered as the Pyrenean foreland basin. Some differences in the fitting parameters can be found between small basins (less than $1000-2000 \mathrm{~km}^{2}$ ) and large basins, with D values of 0.37 and 0.50 , respectively.

\section{Structural patterns}

As we have shown, most of the Iberian foreland basins are related to thrusting and strike-slip faulting. A qualitative classification can be undertaken for the different types of basins, from pop-downs to restraining bends (Figs. 4, 22).

Subsidence along strike-slip fault zones depends on the fault geometry and kinematics (Christie-Blick and Biddle, 1985). Bends and

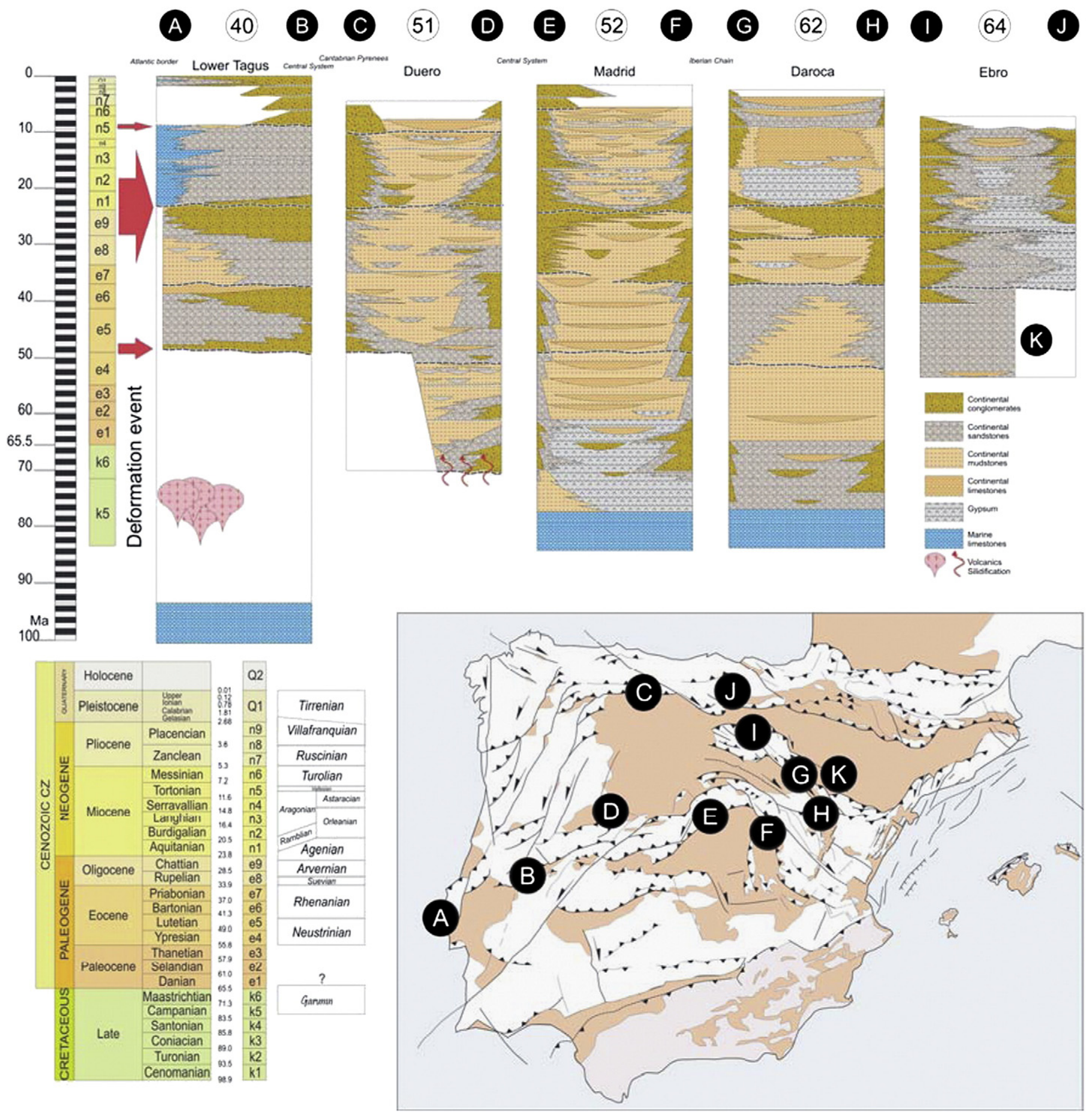

Fig. 20. Qualitative correlation analysis of the sedimentary fill of the main Iberian basins showing the distribution of breaks in sedimentation. From west to east, the Lower Tagus Basin (Cunha et al., 2000) (40), the Duero Basin (north, Herrero et al., 2010, south, Santisteban et al., 1991) (51), the Madrid Basin (Calvo et al., 1993: Alonso-Zarza, 2008) (52), the Daroca-Calatayud basin (Alcalá et al., 2000; Casas et al., 2000) (62) and the Ebro Basin (Civis 2004 in Vera, 2004) (64). Red arrows indicate moments of common basin filling initiation or sedimentary ruptures. Represented basin borders are shown in a tectonic map (see Fig. 2). 


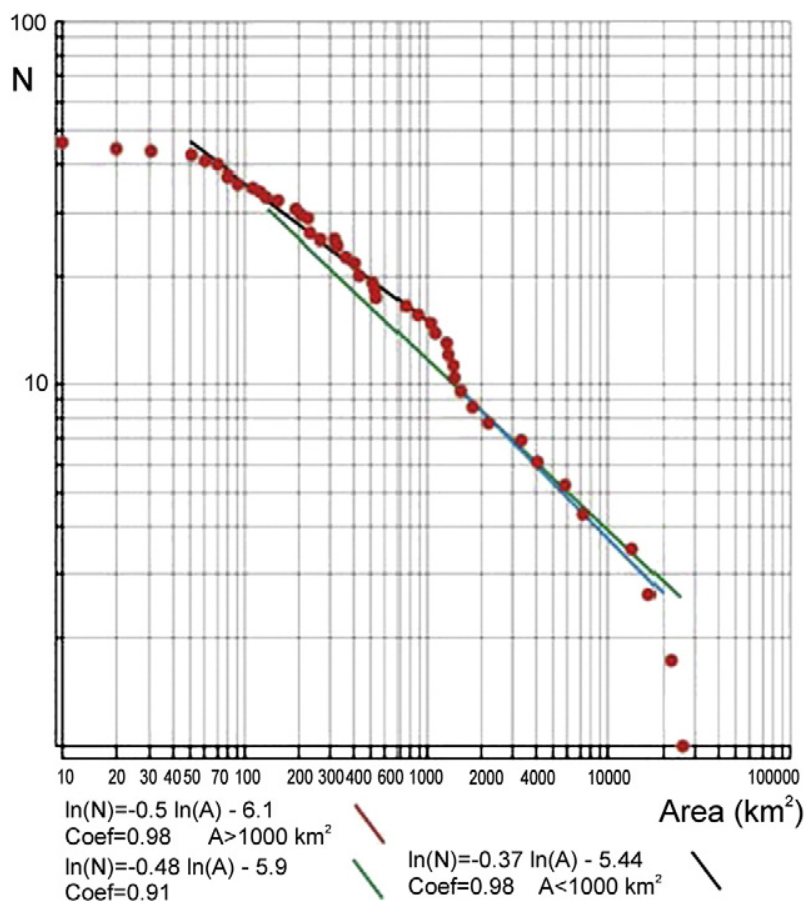

Fig. 21. Size distribution of 55 Cenozoic basins of the Iberian foreland with an area larger than $20 \mathrm{~km}^{2}$ (characteristic lengths, $\mathrm{A}^{1 / 2}, 293$ and $4.5 \mathrm{~km}$ ), finding a fractal dimension (D) of 0.48 (green) in a range between 100 and $20,000 \mathrm{~km}^{2}$. Some differences in the fitting parameters can be found between small basins (less than $1000-2000 \mathrm{~km}^{2}$ ) and large basins, with 0.37 and $0.50 \mathrm{D}$ values respectively (black and red).

stepovers in strike-slip fault zones may give rise to areas with a divergence component, resulting in subsiding areas (releasing bends), or zones with a convergence component, giving rise to uplifting areas bounded by thrusts (restraining bends) (Mann et al., 1984). Releasing bends produce pull-apart-like basins, whereas restraining bends cause one block to override the other, so that sedimentary basins may develop on the thrusted block (Steel et al., 1985; Namson and Davis, 1988). Small piggy-back basins can also develop on the back flank of the local reverse fault.

Restraining bends and releasing bends are commonly elongated, gently-shaped features in map view. With increased strike-slip offset, pull-apart and restraining bend basins may evolve into more rhomboidally-shaped features (Mann et al., 1984).

Most of the main thrusting ranges in Iberia show intramontane pop-downs or thick-skin imbricate thrust systems (e.g. De Vicente et al., 2007a, b). Nevertheless, most of them show stepovers and segmented geometries that in many cases are difficult to separate from those generated at double restraining bends.

We have used the basin classification shown in Fig. 4 to obtain a qualitative distribution of the Iberian foreland basins (Fig. 22). Transtensional basins are found mainly along the Messejana and Vilariça faults in gentle releasing bends. The Régua-Vérin fault basins are also extensional. However, we have only considered those from the $\mathrm{NE}$ fault termination, where a poorly-structured horsetail splay seems to be related to the Verín basin. The same situation occurs at the SE end of the As Pontes fault (Vilalba basin). Transpressional basins are more numerous and appear along the As Pontes, Meirama, Monforte and Ventaniella faults and within the Iberian range. Most of these basins are restraining bends or double restraining bends with sharp contacts between the thrusts and the strike-slip faults. Gentle restraining bends also developed in the Meirama fault and in the Iberian Chain. As mentioned before, the Ventaniella fault in the Cantabrian mountains has produced contractional horsetail splays, both at its NW and SE terminations. Thrust-related basins only outcrop in the Cantabrian mountains and in the Central System, although a large part of the Iberian Chain also overthrusts the Ebro and Madrid basins (Guimerà et al., 2004; Casas-Sainz and Gil-Imaz, 1998). In most cases, these intramontane basins can be classified as sharp segmented pop-downs, whereas the main basins can be considered as open-ramp basins. It is remarkable that pop-down basins do not appear within small ranges, such as the Toledo-Guadalupe mountains, which suggests that they form a part of the Central System.

For a more quantitative (automatic) analysis of such basin geometries, we have measured both types of border faults (Table 1) and then represented them on log-log plots. This is similar to the classic analysis by Aydin and Nur (1982) for push-ups and pull-apart basins, where a typical relationship of three between the length to width ratio was found. As longitudes related to faulting are scale dependent, we first used the ratio $r$ between both kinds of basin border, $r=$ length of strike-slip fault/length of thrust fault (scale independent) against the basin area (Fig. 23). For small basins, a large variation in $r$ values is found. Nevertheless, for basins larger than around $1000 \mathrm{~km}^{2}$ (including the main Iberian foreland basins), a relationship close to a constant $(r=0.6)$ is found. These results may be interpreted from a tectonic perspective: small basins may be related to a single structure (thrust or strike-slip fault) that can impose an $r$ ratio far from 1 . On the contrary, for a certain scale, the entire upper crust is involved in basin development, which means that the $r$ values are the result of bulk deformation conditions which seem to be constant in the Iberian foreland. This constant $r$ value seems to be reached for basin areas larger than $100-1000 \mathrm{~km}^{2}$, and is also related to the deformation depth involved (upper crustal or crustal structures) (Fig. 23). From this point of view, the two most important transpressive deformation belts are the Monforte fault and the Iberian Chain since they have the largest restraining bend basins.

The differentiation of basin types related to contrasting $r$ values becomes clear from cross-plots of strike-slip and dip-slip for each basin (Fig. 24), in which the same line of longitude divides different basin types (thrusting-strike-slip predominance). The extreme ratios will appear when the basin is developed as a gentle bend along a strike-slip fault (e.g. Cabriel basin or basins along the Messejana and Vilariça faults) or as a narrow non-segmented pop-down (e.g. the Cepeda and Lozoya basins at the Central System). We have separated basin groups depending on the $r$ values into three classes $(>3,1-3$, and $<1$ ). r Values larger than 3 correspond to narrow strike-slip basins such as the Vilariça basin (Fig. 9) that follow the relationship found for large strike-slip fault basins (Aydin and Nur, 1982). $r$ Values between 1 and 3 produce gentle (but not necessarily narrow), wider bends with strike-slip-thrusting contacts that are almost perpendicular. The Sarria basin is a good example of this type of basin (Fig. 9). The third type corresponds to thrust rhomboid basins $(1>r>0.3)$, which constitute the dominant basin shape found for the main basins, although the small Amblés basin is also an excellent example (Fig. 14). Thrust elongate basins are scarce, with the Cepeda basin one example of this group (Fig. 14).

It is interesting to note that elongate basins are all small in size, with areas typically less than $100 \mathrm{~km}^{2}$, whereas for large basins, thrust rhomboid is the standard shape (areas larger than $1000 \mathrm{~km}^{2}$ ).

Returning to the qualitative classification (Fig. 22), it can be observed that the mean $r$ value for the transtensional basins (pullapart, releasing bends, double releasing bends, sharp or gentle) is around 3.5. Transpressional basins do not have such a constant value, but rather have $r$ values between 1 and 0.8 , slightly higher than the mean value for the open-ramp basins (main basins) $(r=0.6)$. The highest $r$ values are found for gentle restraining bend basins $(r=5)$, which together with the gentle releasing bend basins can also be more accurately considered as narrow push-down basins, since most of the strike-slip fault-basin contacts have a clear reverse component (e.g. Figs. 9 and 17). 


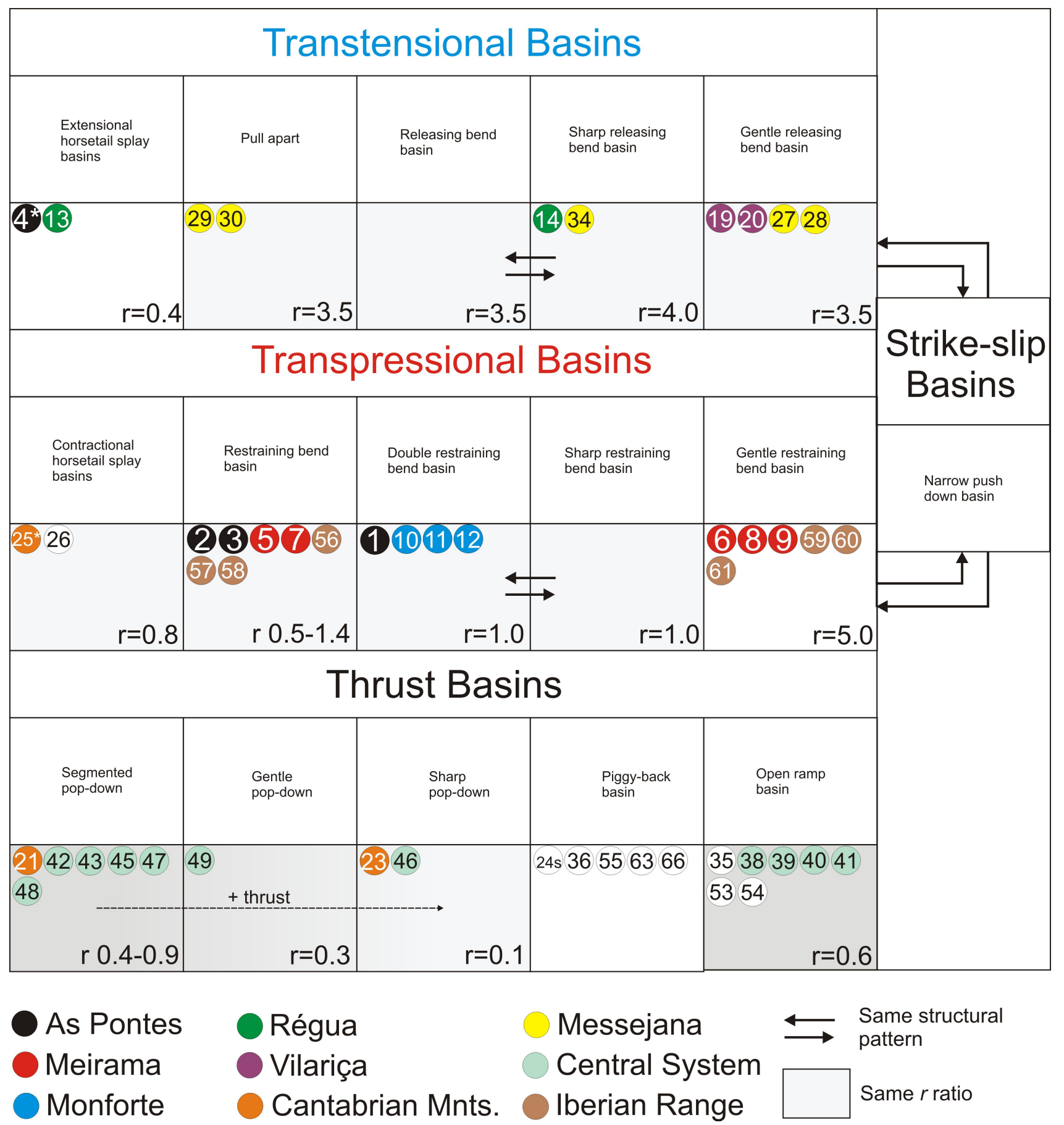

Fig. 22. Qualitative tectonic classification of the Iberian Cenozoic basins. See Figs. 2, 4, 5 and Table 1.

The $r$ values of the thrust basins considered range from 0.4 to 0.9 for segmented pop-downs, to 0.3 for gentle pop-downs and as low as 0.1 for sharp pop-downs. Small open-ramp basins from the Central System (Montego, Moraleja, Lower Tagus, Badajoz, and Campoarañuelo) have an $r=0.6$ mean value that is the same for the main basins (Duero, Madrid, and Ebro).

\section{Discussion}

Most of the Iberian Cenozoic basins have a polyphase deformation history, with different rejuvenation periods. However, even during a single deformation process, basin infilling can be conditioned by the evolution of different tectonic structures. For instance, in the well-studied As Pontes basin, the double (in line) restraining bend is the end stage of the structural evolution of a compressive underlapping stepover (Santanach et al., 2005). However, detailed analyses of this type do not contradict the notion that some constant deformation pattern occurred in the Iberia foreland.

As demonstrated from our analysis of basins with an area larger than $100-1000 \mathrm{~km}^{2}$, the total amount of Cenozoic contractive deformation was distributed between strike-slip and thrust faults with an $r$ ratio close to 0.6 . However, for small basins this parameter seems to depend on the type of fault, range or deformation belt (pure strike-slip, transtension, transpression, and pop-up) independently of the local tectonic development. 


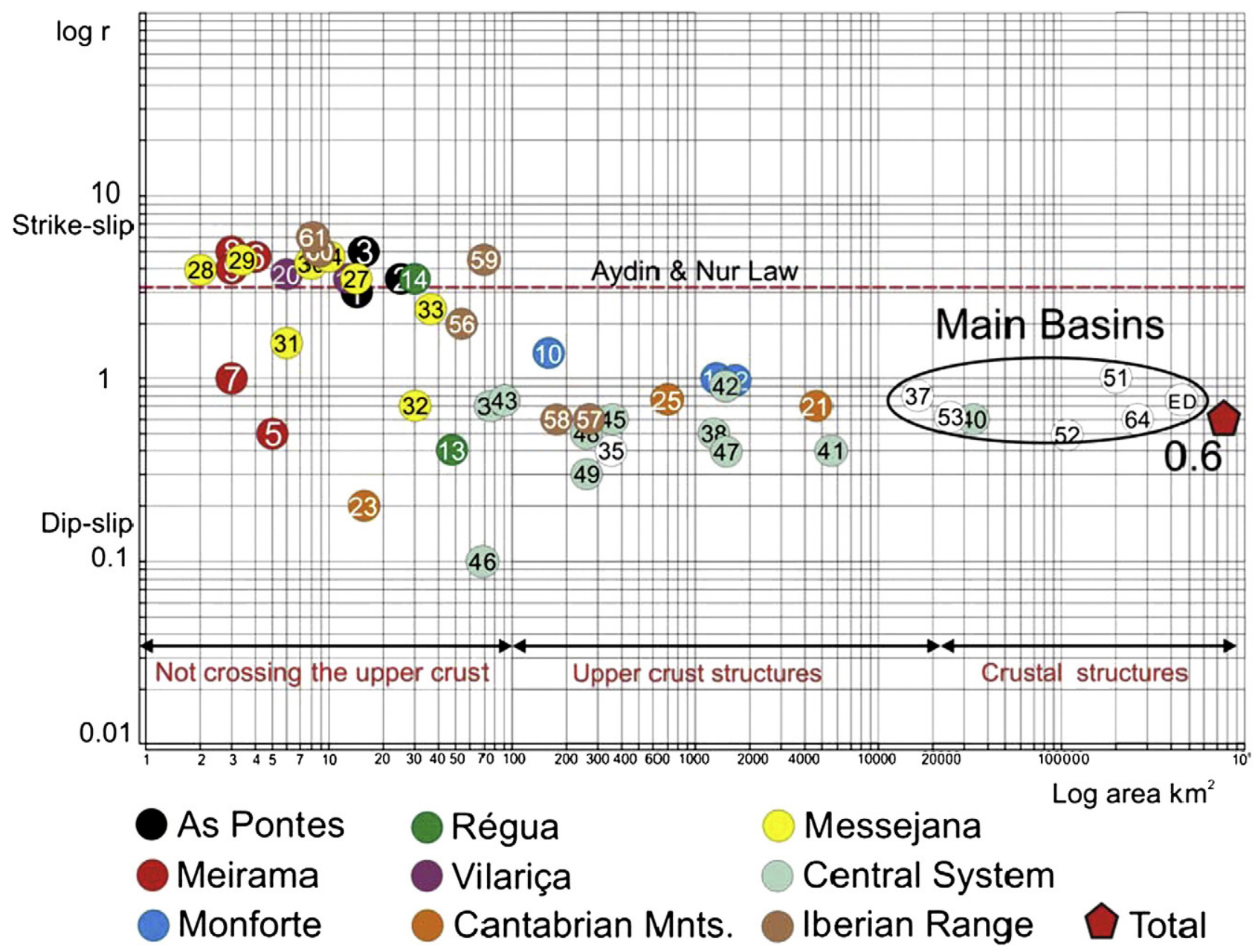

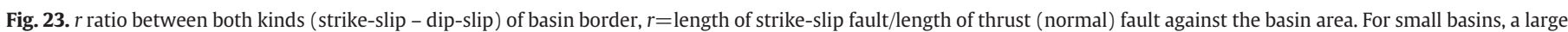

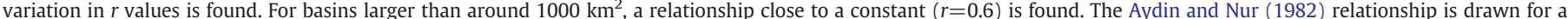
comparison.

Strike-slip and thrust-fault basin settings are closely related to upper crustal or whole crustal structures. Consequently, different upper crustal fault motions underlying formation of the large basins must be compensated by deformation of the lower crust, whereas small basins can be accommodated in bends or pop-downs that do not cross the entire upper crust, even though the main fault can be a crustal structure. Intermediate situations can be found for basin areas between 100 and $1000 \mathrm{~km}^{2}$, mainly in the western part of the Vilariça Fault System (at the Monforte fault) and within the Iberian Chain.

\section{Conclusions}

The intense intraplate deformation of the Iberian microcontinent and its elevated topography is the result of a process of crustal shortening connected to the N-S, Oligocene-late Miocene AfricaEurope convergence and to the roughly $\mathrm{N}-\mathrm{S} \mathrm{S}_{\text {hmax }}$ transmitted stresses. In their lithospheric context, most of the Iberian basins can be regarded as compressional basins formed by lithospheric folding. Deformation was also conditioned by the structural position of Iberia (underthrusted plate), producing, broadly speaking, pro-foreland basins.

The ranges formed by crustal buckling in Iberia are distributed in three structural uplifts containing the main crustal thrusts that are sectored by left-lateral NNE-SSW and right-lateral NW-SE strike-slip deformation belts. Bordering and within these ranges and strike-slip faults, frequently intramontane basins developed. Excluding the extensional basins, more than sixty basins can be mapped. We have examined the basins outcropping along the As Pontes, Meirama, Monforte, Régua-Verín, Vilariça, Ventaniella and Messejana (AlentejoPlasencia) faults and those from the Central System and the Iberian Chain, together with the main foreland basins (Ebro, Duero, Madrid, Lower Tagus and Badajoz).

An analysis of the sedimentary infilling of these basins allows us to deduce that a common overall evolution occurred. Results from backstripping and sedimentary infilling analyses indicate that the main trends can be summarised in four stages:

1. The first major paleogeographic change occurred at the early to middle Eocene transition, with the opening of a large number of sedimentary basins.

2. During the Oligocene-Early Miocene, sedimentary basin filling was characterised by the development of several tectono-stratigraphic units, separated by sedimentary breaks.

3. During the early to middle Miocene, the previously pronounced topography was smoothed, followed by significant expansion of lake systems, which first were infilled with evaporitic sediments.

4. Towards the middle Tortonian (Upper Vallesian) a very significant paleogeographic change took place, with the generation of important relief and piedmont sedimentation; the transition from endorheic to exorheic regime took place in some of these basins.

The largest number of breaks in sedimentation occurred over the 30 to $15 \mathrm{Ma}$ time span, with a relative maximum around the Oligocene-Miocene transition (22 Ma). Sedimentary infilling 


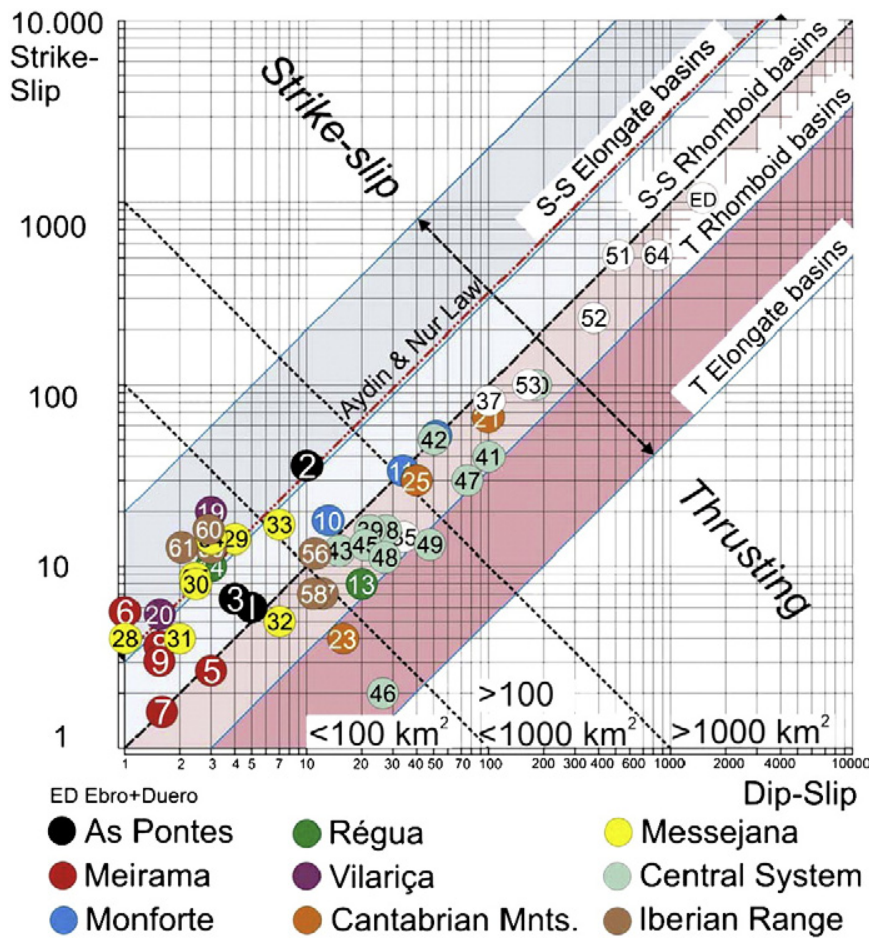

Fig. 24. Direct plot of both lengths for each basin (Fig. 23). The same line of longitude divides different basin types (thrusting -strike-slip predominance). Extreme ratios appear when the basin is developed as a gentle bend along a strike-slip fault or as a narrow non-segmented pop-down. We have separated basin groups depending on the $r$ values using a factor of 3: strike-slip elongate basins (blue), strike-slip rhomboid basins (light blue), thrust rhomboid basins (pink) and thrust elongate basins (red). Thrust rhomboid basins $(1>r>0.3)$ constitute the dominant basin type found for the main basins. The equivalent Aydin and Nur (1982) is drawn for a comparison.

processes start eastwards, showing a westward temporal shift at the onset of accelerated subsidence.

The general intraplate sedimentary evolution of the Iberian foreland basins is also evident through their genetically-related structural and tectonic framework, which shows some remarkable interrelated features (e.g. basin size, type of border faults, and tectonic setting):

a) The size distribution of fifty five of these basins follows a powerlaw with a fractal dimension (D) of 0.48 in a range between 100 and $20,000 \mathrm{~km}^{2}$. Remarkably, this analysis shows a better fractal distribution if the Ebro and Duero basins are considered as a single basin (Pyrenean foreland basin). This result reinforces the notion of a common tectonic evolution for all these basins.

b) From a qualitative tectonic analysis, transtensional basins are found mainly westwards along the Messejana and Vilariça faults in gentle releasing bends. Transpressional basins are more numerous and appear along the As Pontes, Meirama, Monforte and Ventaniella faults and within the Iberian Range. Most of these basins are restraining bends or double restraining bends with sharp contacts between the thrusts and the strike-slip faults. Thrust-related basins only outcrop in the Cantabrian mountains and in the Central System. They can be classified as sharp segmented pop-downs, whereas the main basins can be considered as open-ramp basins.

c) A quantitative analysis of such basin geometries has also been undertaken by measuring the type of border faults in terms of the $r$ ratio $=$ length of strike-slip fault/length of thrust fault against the basin area. For small basins (less than $100 \mathrm{~km}^{2}$ ) a large variation in $r$ values is found. For basin areas larger than $100 \mathrm{~km}^{2}$, an average $r=0.6$ is found. In our interpretation most of the small basins are related to a single, mostly strike-slip, structure that may impose an $r$ ratio in excess of 1 . On the contrary, for larger basins, the deformation distributed through the entire upper crust becomes progressively more involved in basin development, which means that the $r$ values are the result of bulk deformation conditions which seem to be remarkably constant in the Iberian foreland.

d) The differentiation of basin types in terms of contrasting $r$ values becomes more evident from cross-plots of strike-slip and dip-slip. Extreme ratios appear when the basin is developed as a gentle bend along a strike-slip fault or as a narrow non-segmented popdown. We have separated basin groups depending on the $r$ values into three classes $(>3,1-3$, and $<1)$ : Thrust rhomboid basins $(1>r>0.3)$ constitute the dominant basin type found for the main basins. It is interesting to note that elongate basins are all small in size $(r>3)$ and marked by both strike-slip and thrust bounding faults, with areas typically less than $100 \mathrm{~km}^{2}$. Values of $r$ between 1 and 3 produce gentle, wider bends with strike-slip-thrusting contacts that are almost perpendicular.

By combining all these features with the tectonic analysis, it can be seen that the mean $r$ value for the transtensional basins (pull-apart, releasing bends, double releasing bends, sharp or gentle) is around 3-5. Transpressional basins do not have such a constant value, but rather have $r$ values between 1 and 0.8 , slightly higher than the mean value for the open-ramp basins (main basins) $(r=0.6)$. The highest $r$ values are found for gentle restraining bend basins $(r=5)$, which together with the gentle releasing bend basins can also be more accurately considered as narrow push-down basins.

The $r$ values of the thrust basins considered range from 0.4 to 0.9 for segmented pop-downs to 0.3 for gentle pop-downs and as low as 0.1 for sharp pop-downs. Small open-ramp basins from the Central System have an $r=0.6$ mean value, which is the same as that for the main basins (Duero, Madrid and Ebro).

Interestingly, for basins with an area larger than $100-1000 \mathrm{~km}^{2}$, the total amount of Cenozoic contractive deformation was distributed between strike-slip and thrust faults with an $r$ ratio close to 0.6. However, for small basins this parameter seems to depend on the type of fault, range or deformation belt (pure strike-slip, transtension, transpression, and pop-up) independently of its local tectonic development. Intermediate situations can be found for basin areas between 100 and $1000 \mathrm{~km}^{2}$ mainly in the western part of the Vilariça Fault System (at the Monforte fault) and within the Iberian Chain.

\section{Acknowledgements}

This study was supported by Consolider Ingenio 2006 “Topoiberia” CSD2006-00041 and Spanish National Research Program CGL200613926-C02-01-02 “Topoiberia Foreland”.

\section{References}

Alcalá, L., Alonso-Zarza, A.M., Alvarez-Sierra, M.A., Azanza, B., Calvo, J.P., Cañaveras, J.C., van Dam, J.A., Garcés, M., Kirijgsman, W., van der Meulen, A.J., Morales, J., PeláezCampomanes, P., Pérez-González, A., Sánchez-Moral, S., Sancho, R., Sanz-Rubio, E., 2000. El registro sedimentario y faunístico de las cuencas de Calatayud-Daroca y Teruel. Evolución paleoambiental y paleoclimática durante el Neógeno. Rev. Soc. Geol. Esp. 13 (2), 323-343.

Alonso, A., Pagés, J.L., 2007. Stratigraphy of Late Pleistocene coastal deposits in Northern Spain. J. Iberian Geology 33 (2), 207-220.

Alonso, J.L., Pulgar, J.A., García-Ramos, J.C., Barba, P., 1996. Tetiary basins and Alpine tectonics in the Cantabrian Mountains (NW Spain). In: Friend, P.F., Dabrio, C.J. (Eds.), Tertiary Basins of Spain. Cambridge Univ. Press, pp. 214-218.

Alonso-Zarza, A., 2008. El Neógeno: de las crisis tectónicas a la tranquilidad de los lagos someros. In: Calonge, A., Rodríguez, M., Segura, M. (Eds.), Geología de Guadalajara, pp. 151-165.

Álvaro, M., Capote, R., Vegas, R., 1979. Un modelo de evolución geotectónica para la Cadena Celtibérica. Acta Geol. Hisp. 14, 172-177.

Anadón, P., Cabrera, L., Roca, E., 1989. Contexto estructural y paleogeográfico de los sistemas lacustres cenozoicos de España. Acta Geol. Hisp. 24 (3-4), 167-184.

Andeweg, B., De Vicente, G., Cloetingh, S., Giner, J.L., Muñoz Martín, A., 1999. Local stress fields and intraplate deformation of Iberia: variations in spatial and temporal interplay of regional stress sources. Tectonophysics 305, 153-164. 
Aydin, A., Nur, A., 1982. Evolution of pull-apart basins and their scale independence. Tectonics 1 (1), 91-105.

Strike-slip deformation, basin formation and sedimentation. In: Biddle, K.T., ChristieBlick, N. (Eds.), Sepm Sp. Publ., 37.

Bird, P., 2003. An updated digital model of plate boundaries. Geochem. Geophys. Geosyst. 4 (3), 1027

Cabral, J., 1989. An example of intraplate neotectonic activity, Vilaiça Basin, NE Portugal. Tectonics 8 (2), 285-303.

Cabral, J., 1995. Neotectónica de Portugal continental. Mem. Inst. Geol. Mineiro Port. 31, 265 .

Cabral, J., Ribeiro, A., 1990. Neotectonic studies in Portugal - the neotectonic Map. Bull. INQUA Neotectonics Comm. 13, 6-8.

Cabral, J., Cunha, P., Martins, A., Ribeiro, A., 2007. Late Cenozoic vertical tectonic displacements in mainland Portugal (West Iberia). Geophys. Res. Abstr. 9, 01591.

Calvo, J.P., 2004. Rasgos comunes de las Cuencas cenozoicas. In: Vera, J.A. (Ed.), Geología de España. SGE, IGME, Madrid, pp. 584-586.

Calvo, J.P., Daams, R., Morales, J., López-Martínez, N., Agustí, J., Anadón, P., Armenteros, I., Cabrera, L., Civis, J., Corrochano, A., Diaz-Molina, M., Elízaga, E., Hoyos, M., MartínSuárez, E., Martínez, J., Moissenet, E., Muñoz, A., Pérez-García, P., Pérez-González, A., Portero, J.M., Robles, F., Santisteban, C., Torres, T., Van der Meulen, A.J., Vera, J.A., Mein, P., 1993. Up-to-date Spanish continental Neogene synthesis and paleoclimatic interpretation. Rev. Soc. Geol. Esp. 6, 1-16.

Casas, A.M., Casas, A., Pérez, A., Tena, S., BArrier, L., GApais, D., Nalpas, T., 2000. Syntectonic sedimentation and thrust-and-fold kinematics at the intra-mountain Montalbán Basin (northern Iberian Chain, Spain). Geodin. Acta 1, 1-17.

Casas-Sainz, A.M., Gil-Imaz, A., 1998. Extensional subsidence, contractional folding and thrust inversion of the eastern Cameros Basin, northern Spain. Geol. Rundsch. 86 (4), 802-818.

Christie-Blick, N., Biddle, K., 1985. Deformation and basin formation along strike-slip faults. In: Biddle, K.T., Christie-Blick, N. (Eds.), Strike-slip deformation, basin formation, and sedimentation: Society of Economic Paleontologists and Mineralogists Special Publication, 37, pp. 1-34.

Civis, J. (Ed.), 2004. Cuencas Cenozoicas. Cap.6. Geología de España. SGE-IGME, pp. 529-586.

Cloetingh, S., Ziegler, P.A., 2007. Tectonic models for the evolution of sedimentary basins. Treatise on Geophysics, 6. Elsevier, pp. 486-598.

Cloetingh, S., Van der Veek, P.A., Van Rees, D., Roep, T., Biermann, C., Stephenson, R.A. 1992. Flexural interaction and dynamics of the Neogene extensional basin formation in the Alborán-Betic Region. Geo-Mar. Lett. 12, 157-164.

Cloetingh, S., Burov, E., Beekman, F., Andeweg, B., Andriessen, P.A.M., GarciaCastellanos, D., De Vicente, G., Vegas, R., 2002. Lithospheric folding in Iberia. Tectonics 21 (5), 1041-1067.

Crowell, J.C., 1974. Origin of Late Cenozoic basins in southern California. Spec. Publ. Soc. Econ. Paleontol. Mineral. 22, 190-204.

Cunha, P.P., 1987. Evolução tectono-sedimentar terciária da região de Sarzedas (Portugal). Comun. Serv. Geol. Port. 73 (1/2), 67-84

Cunha, P.P., 1992. Estratigrafia e sedimentologia dos depósitos do Cretácico Superior e Terciário de Portugal Central, a leste de Coimbra. PhD thesis, Univ. Coimbra, 262 p.

Cunha, P.P., 1996. Unidades litostratigráficas do Terciário da Beira Baixa (Portugal). Comun. Inst. Geol. Mineiro Lisb. 82, 87-130.

Cunha, P.P., 1999. Unidades litostratigráficas do Terciário na região de Miranda do Corvo-Viseu (Bacia do Mondego - Portugal). Comun. Inst. Geol. Mineiro Lisb. 86, 143-196.

Cunha, P.P., Pena dos Reis, R., 1995. Cretaceous sedimentary and tectonic evolution of the northern sector of the Lusitanian Basin. Cretaceous Res. 16, 155-170.

Cunha, P.P., Pereira, D.I., 2000. Cenozoic evolution of the Longroiva-Vilariça area (NE Portugal) Ciências da Terra (UNL). Lisboa 14, 91-100.

Cunha, P.P., Barbosa, B.P., Pena dos Reis, R., 1993. Synthesis of the Piacenzian onshore record, between the Aveiro and Setúbal parallels (Western Portuguese margin), Ciências da Terra, Univ. Nova Lisb. 12, 35-43.

Cunha, P.P., Pimentel, N., Pereira, D.I., 2000. Sedimentary and tectonic signature of the betic compression climax in Portugal. The late Vallesian-Turolian sedimentary discontinuity. Ciênc. Terra UNL Lisb. 14, 61-72.

Cunha, P.P., Martins, A.A., Daveau, S., Friend, P.F., 2005. Tectonic control of the Tagus river fluvial incision during the late Cenozoic, in Ródão-central Portugal (Atlantic Iberian border). Geomorphology 64, 271-298.

Cunha, P.P., Martins, A.A., Huot, S., Murray, A., Raposo, L., 2008. Dating the Tagus River lower terraces in the Ródão area (Portugal) to assess the role of tectonics and uplift. Geomorphology 102, 43-54.

Cunningham, D., 2005. Active intracontinental transpressional mountain building in the Mongolian Altai: defining a new class of orogen. Earth Planet. Sci. Lett. 240 (2), 436-444.

Cunningham, W.D., Mann, P., 2007. Tectonics of strike-slip restraining and releasing bends. Geol. Soc. Lond. Spec. Publ. 290, 1-12.

De Bruijne, C.H., 2001. Denudation, intraplate tectonics and far fields effects in central Spain. PhDthesis, Free Univ. Amsterdam, 164 p.

De Bruijne, C.H., Andriessen, P., 2002. Far field effects of alpine plate tectonicism in the Iberian micriplate recorded by fault-related denudation in the Spanish Central System. Tectonophysics 349, 161-184.

Desegaulx, P., Kooi, H., Cloetingh, S., 1991. Consequences of foreland basin development on thinned continental lithosphere: application to the Aquitaine basin (SW France). Earth Planet. Sci. Lett. 106, 106-132.

De Vicente, G., Vegas, R., 2009. Large-scale distributed deformation controlled topography along the western Africa-Eurasia limit: tectonic constrains. Tectonophysics $474,124-143$.

De Vicente, G., Muñoz Martín, A., Vegas, R., Cloetingh, S., Casas, A., González Casado, J.M., Álvarez, J., 2005a. Neutral points and constrictive deformation in paleostresses analysis: the Cenozoic contraction of Iberia. Geophys. Res. Abstr. 7, 04272.

De Vicente, G., Elorza, F.J., Olaiz, A., García-Castellanos, D., Muñoz-Martín, A., Vegas, R. Alvarez, J., 2005b. Number-size distribution invariance of Iberian Cenozoic basins. Geophys. Res. Abstr. 7, 04296.

De Vicente, G., Vegas, R., Muñoz-Martín, A., Silva, P.G., Andriessen, P., Cloetingh, S., González-Casado, J.M., Van Wees, J.D., Álvarez, J., Carbó, A., Olaiz, A., 2007a. Cenozoic thick-skinned and topography evolution of the Spanish Central System. Glob. Planet. Change 58, 335-381.

De Vicente, G., González-Nistal, S., Muñoz-Martín, A., Vegas, R., Olaiz, A., FernándezLozano, J., de Vicente, R., 2007b. El cabalgamiento cenozoico de Boinás (Cordillera Cantábrica, España). Geogaceta 42, 7-10.

De Vicente, G., Cloetingh, S., Muñoz-Martín, A., Olaiz, A., Stich, D., Vegas, R., GalindoZaldivar, J., Fernández-Lozano, J., 2008a. Inversion of moment tensor focal mechanisms for active stresses around Microcontinent Iberia: tectonic implications. Tectonics 27, 1-22.

De Vicente, G., Vegas, R., Cabral, J., Van Wees, J.D., Olaiz, A., 2008b. Cenozoic strike-slip corridors of the Iberian Peninsula. Geotemas 4, 14-18.

De Vicente, G., Vegas, R., Muñoz-Martín, A., Van Wees, J.D., Casas-Sáinz, Sopeña A., Sánchez-Moya, Y., Arche, A., López-Gómez, J., Olaiz, A., Fernández-Lozano, J., 2009 Oblique strain partitioning and transpression on an inverted rift: the Castilian Branch of the Iberian Chain. Tectonophysics 470, 224-242.

Dinis, J., Rey, J., Cunha, P.P., Callapez, P., Pena dos Reis, R., 2008. Stratigraphy and allogenic controls of the western Portugal Cretaceous: an updated synthesis. Cretaceous Res. 29, 772-780.

Escuder-Viruete, J., Carbonell, R., Jurado, M.J., Martí, D., Pérez-Estaún, A., 2001. A Twodimensional geostatistical modelling and prediction of the fracturation in the Albala granitic pluton, SW Iberian Massif, Spain. J. Struct. Geol. 23, 2011-2023.

Fernández-Lozano, J., Sokoutis, D., Willingshofer, E. De Vicente, G. and Cloetingh, S, 2010. Cenozoic deformation of Iberia: a model for intraplate mountain building and basin development based on analogue modelling. Tectonics (accepted).

Ferreira-Soares, A., Fonseca-Marques, J., Rocha, R.E.B., Cunha, P.P., Pinto-Duarte, L.V., Sequeira, A.J.D., Bernardo de Sousa, M., Gama-Pereira, L.C., Gomes, E., Pereira, E. and Rola dos Santos, J., 2005. Carta Geológica de Portugal, Folha 19-D, Coimbra-Lousã 1:50000, Instituto de Engenharia, Tecnología e Inovação.

Friend, P.F., Dabrio, C.J. (Eds.), 1996. Tertiary basins of Spain. The stratigraphic record of crustal kinematics. : World and Regional Geology, 6. Cambridge University Press, Cambridge, pp. 1-400.

Gallastegui, J., 2000. Estructura cortical de la Cordillera y margen Cantábricos: Perfiles ESCI-N. Trab. Geol. 22, 221.

Gibbons, W., Moreno, T., 2002. The Geology of Spain. Geological Society, London. 649 p.

Guimerà, J., 1988. Estudi estructural de l'enllaç entre la Serralada Iberica y la Serralada Costanera Catalana. Tesis doctoral, Univ. Barcelona, 600 p.

Guimerà, J., Más, R., Alonso, A., 2004. Intraplate deformation in the NW Iberian Chain: Mesozoic extension and contractional inversion. J. Geological Soc. Lond. 16 291-303.

Heredia, N., Rodríguez-Fernánde, L.R., Vegas, R., De Vicente, G., Cloetimgh, S., Giner, J. González-Casado, J.M., 2004. Cadenas cenozoicas del Noroeste peninsular. In: Vera, J.A. (Ed.), Geología de España. SGE-IGME, Madrid, pp. 619-621.

Herrero, A., Alonso-Gavián, G., Colmenero, J.R., 2010. Depositional sequences in foreland basin (north-western domain of the continental Duero Basin, Spain). Sed. Geol. 223, 235-264.

Janssen, M.E., Thorne, M., Cloetingh, S., Banda, E., 1993. Pliocene uplift of the eastern Iberian margin: inferences from quantitartive modelling of the Valencia Trough. Earth Planet. Sci. Letts. 119, 585-597.

Lanaja, J.M., 1986. Contribución de la explotación petrolífera al conocimiento de la geología de España. Instituto Geológico y Minero de España. 465 p.

Lopes, F.C., Cunha, P.P., 2007. Tectono-sedimentary phases of the latest Cretaceous and Cainozoic compressive evolution of the Algarve margin (southern Portugal) Chapter 6. In: Nichols, G.J., Williams, E.A., Paola, C. (Eds.), Sedimentary processes, environments and basins -a tribute to Peter Friend. : IAS Special Publication, 38 Wiley-Blackwell Publishing LTD. 642 p.

Lopes, F.C., Cunha, P.P., Le Gall, B., 2006. Cenozoic seismic stratigraphy and tectonic evolution of the Algarve margin (offshore Portugal, southwestern Iberian Peninsula). Mar. Geol. 231 (1-4), 1-36.

López-Olmedo, F., Montes, M.J., Nozal, F., Luengo, J., 2005. Unidades litoestratigráficas del Terciario del sector de Sepúlveda-Ayllón. Borde suroriental de la Cuenca de Duero. Geogaceta 38, 75-78.

Mann, P., Burke, K., Matumoto, T., 1984. Neotectonics of the Hispaniola: plate motion, sedimentation and seismicity at a restraining bend. Earth Planet. Sci. Lett. 70 311-324.

Marín, J.A., Pulgar, J.A., Alonso, J.L., 1995. La deformación alpina en el Domo de Valsurvio (Zona Cantábrica, NO de España). Rev. So. Geol. Esp. 8 (1-2), 111-116.

Martín-González, F., 2009. Cenozoic tectonic activity in a Variscan basement: evidence from geomorphological markers and structural mapping (NW Iberian Massif. Geomorphology (accepted). doi: 10.1016/j.geomorph.2008.12.008.

Martín-González, F., Heredia, N., 2010. Complex tectonic and tectonostratigraphic evolution of an Alpine foreland basin: the western Duero Basin and the related Tertiary depressions of the NW Iberian Peninsula. Tectonophysics. doi:10.1016/j. tecto.2010.03.002

Martins, A.A., Cunha, P.P., Huot, S., Murray, A., Buylaert, J.P., 2009. Geomorphological correlation of the tectonically displaced Tagus River terraces (Gavião-Chamusca area, central Portugal) supported by luminescence dating. Quatern. Int. 199, 75-91.

Monino Sáez, M. Díaz de Terán, J.R., Cendrero, A., 1988. Pleistocene sea level changes in the Cantabrian Coast, Spain. Geomorph. Environ. 351-364. 
Muñoz, J.A., 1985. Estructura alpina i herciniana a la vora sud de la zona axial del Pirineu oriental. Phd. Thesis. Universitat de Barcelona, 305 p.

Muñoz, J.A., 1992. Evolution of a continental collision belt: ECORS-Pyrenees crustal balanced section. In: McClay, K.R. (Ed.), Thrust Tectonics. Chapman \& Hall, London, pp. 235-246.

Muñoz-Martín, A., Cloetingh, S., De Vicente, G., Andeweg, B., 1998. Finite-element modelling of Tertiary paleostress fields in the eastern part of the Tajo Basin. Tectonophysics 300, 47-62.

Namson, J.S., Davis, T.L., 1988. Seismically active fold and thrust belt in the San Joaquin Valley, central California. Geol. Soc. Am. Bull. 100, 257-273.

Naylor, M., Sinclair, H.D., 2008. Pro- vs. retro-foreland basins. Basin Res. 20, 285-303.

Pena dos Reis, R., Cunha, P.P., Dinis, J.L., Trincão, P.R., 2000. Geologic evolution of the Lusitanian Basin (Portugal) during the Late Jurassic. GeoResearch Forum, 6. Transtec Publications, Zurich, pp. 345-356.

Pereira, E. (coord.)., 2000. Folha 2 da Carta Geológica de Portugal, escala 1/200000. INETI, Lisboa.

Querol, R., 1989. Geología del subsuelo de la Cuenca del Tajo. E.T.S.I. Minas de Madrid Depto. de Ingeniería Geológica. 48 p.

Ribeiro, A., Cabral, J., Baptista, R., Matias, L., 1996. Stress pattern in Portugal mainland and the adjacent Atlantic region, West Iberia. Tectonics 15 (2), 641-659.

Santanach, P., 1994. Las cuencas terciarias Gallegas en la termianción occidental de los relieves pirenáicos. Cuad. Lab. Xeol. Laxe 19, 57-71.

Santanach, P., Ferrús, B., Cabrera, L., Sáez, A., 2005. Origin of a restraining bend in an evolving strike-slip system: the Cenozoic As Pontes basin (NW Spain). Geol. Acta 3 (3), 225-239.

Santisteban, J.I., Mediavilla, R., Martín-Serrano, A., 1991. El Paleógeno del sector suroccidental de la Cuenca del Duero: nueva división estratigráfica y controles sobre su sedimentación. Acta Geol. Hisp. 26 (2), 133-148.

Sequeira, A. Cunha, P.P. Sousa, M.B., 1997. A reactivação de falhas, no intenso contexto compressivo desde meados do Tortoniano, na região de Espinhal-Coja-Caramulo (Portugal Central). Comun. Inst. Geol. Mineiro Lisb. 83, 95-126.

Steel, R., Gjelberg, J., Helland-Hansen, W., Kleinsphen, K., Nottvedt, A., Rye-Larsen, M. 1985. The Tertiary strike-slip basins and orogenic belt of Spitsbergen. In: Biddle, K.T., Christie-Blick, N. (Eds.), Strike-slip deformation, basin formation and sedimentation: Society of Economic Paleontologists and Mineralogists Special Publication, 37, pp. 227-264.

Tchalenko, J.S., Ambraseys, N.N., 1970. Structural analysis of the Dasht-e Bayaz (Iran) earthquake fractures. Geol. Soc. Am. Bull. 81, 41-60.

Teixell, A., 1998. Crustal structure and orogenic material budget in the west-central Pyrenees. Tectonics 17, 395-406.
Teixell, A., Arboleya, M.L., Julivert, M., Charroud, M., 2003. Tectonic shortening and topography in the central High Atlas (Morocco). Tectonics 22 (5), 1051-1071.

Torres, T., Ortiz, J.E., Arribas, I., 2006. El anticlinal y las discordancias de Pareja (Guadalajara): definición de las unidades cenozoicas de la Depresión Intermedia (provs. Cuenca y Guadalajara, España). Estudios Geológicos, 62 (1), 89-102.

Turcotte, D.L., 1997. Fractals and Chaos in Geology and Geophysics. Cambridge University Press. $120 \mathrm{p}$.

Van Wees, J.D., Arche, A, Beijdorff, C.G., Lopez-Gomez, J., Cloetingh, S., 1998. Temporal and spatial variations in tectonic subsidence in the Iberian Basin (E Spain). Tectonophysics 300, 285-310.

Vegas, R., 2005. Deformación alpina de macizos antiguos. El caso del Macizo Ibérico (Hespérico). Bol. R. Soc. Esp. Hist. Nat. Sec. Geol 100 (1-4), 39-54.

Vegas, R., 2006. Modelo tectónico de formación de los relieves montañosos y las cuencas de sedimentación terciarias del interior de la Península Ibérica. Bol. R. Soc. Esp. Hist. Nat. Sec. Geol 101 (1-4), 31-40.

Vegas, R., De Vicente, G., Muñoz Martín, A., Palomino, R., 2004. Los corredores de fallas de Régua-Verín y Vilariça: zonas de transferencia de la deformación intraplaca en la península ibérica. Geotemas 6 (5), 245-249.

Vera, J.A. (Ed.), 2004. Geología de España. SGE-IGME, Madrid. 884 p.

Vergés, J., 1999. Estudi Geologic Del Vessant Sud Del Pirineu Oriental I Central. In: Evolucio Cinematica En 3d (Ed. by Colleccio Monografies Tecniques, 7, 194). Institut Cartografic de Catalunya, Barcelona. $521 \mathrm{p}$.

Vergés, J., Fernàndez, M., 2006. Ranges and basins in the Iberian Peninsula: their contribution to the present topography. In: Gee, D.G., Stephenson, R.A. (Eds.), European lithosphere dynamics: Geological Society, London, Memoirs, 32, pp. 223-234.

Vergés, J., Millán, H., Roca, E., Muñoz, J.A., Marzo, M., Cirés, J., den Bezemer, T., Zoetemeijer, R., Cloetingh, S., 1995. Eastern Pyrenees and related foreland basins: pre-, syn- and post-collisional crustal-scale cross-sections. In: Cloetingh, Durand, Puigdefàbregas (Eds.), Marine and Petroleum Geology, 12 (8), pp. 903-916.

Vergés, J., Marzo, M., Santaeulària, T., Serra-Kiel, J., Burbank, D.W., Muñoz, J.A., Giménez-Montsant, J., 1998. Quantified vertical motions and tectonic evolution of the SE Pyrenean foreland basin. In: Mascle, A., Puigdefàbregas, C., Luterbacher, H.P., Fernàndez, M. (Eds.), Cenozoic Foreland Basins of Western Europe. Geological Society Special Publications, 134, pp. 107-134.

Vergés, J., Marzo, M., Muñoz, J.A., 2002. Growth strata in foreland settings. Sed. Geol. $146,1-9$.

Villamor, P., 2002. Cinemática terciaria y cuaternaria de la falla de Alentejo-Plasencia y su influencia en la peligrosidad sísmica del interior de la península Ibérica. PhD Thesis. Universidad Complutense de Madrid. 343 p. 